\title{
A Nonsecosteroidal Vitamin D Receptor Modulator Ameliorates Experimental Autoimmune Encephalomyelitis without Causing Hypercalcemia
}

\author{
Songqing Na, ${ }^{1}$ Yanfei Ma, ${ }^{1}$ Jingyong Zhao, ${ }^{1}$ Clint Schmidt, ${ }^{2}$ Qing Q. Zeng, \\ Srinivasan Chandrasekhar, ${ }^{1}$ William W. Chin, ${ }^{3}$ and Sunil Nagpal ${ }^{4}$ \\ ${ }^{1}$ Lilly Research Laboratories, Eli Lilly and Company, Lilly Corporate Center, Indianapolis, IN 46285, USA \\ ${ }^{2}$ Research Opetation, NovaDigm Therapeutics, Inc., Grand Forks, ND 58202, USA \\ ${ }^{3}$ Harvard Medical School, Harvard University, Boston, MA 02215, USA \\ ${ }^{4}$ Respiratory and Immunology, External Discovery and Preclinical Sciences, Merck Research Laboratories, West Point, PA 19486, USA
}

Correspondence should be addressed to Songqing Na, na_songqing@lilly.com and Sunil Nagpal, sunil.nagpal@merck.com

Received 3 October 2010; Revised 10 December 2010; Accepted 19 December 2010

Academic Editor: Rachel Farrell

Copyright (c) 2011 Songqing Na et al. This is an open access article distributed under the Creative Commons Attribution License, which permits unrestricted use, distribution, and reproduction in any medium, provided the original work is properly cited.

\begin{abstract}
Vitamin D receptor (VDR) agonists are currently the agents of choice for the treatment of psoriasis, a skin inflammatory indication that is believed to involve an autoimmune component. 1,25-dihydroxyvitamin D3 [1,25- $\left.(\mathrm{OH})_{2} \mathrm{D}_{3}\right]$, the biologically active metabolite of vitamin $\mathrm{D}$, has shown efficacy in animal autoimmune disease models of multiple sclerosis, rheumatoid arthritis, inflammatory bowel disease, and type I diabetes. However, the side effect of $1,25-(\mathrm{OH})_{2} \mathrm{D}_{3}$ and its synthetic secosteroidal analogs is hypercalcemia, which is a major impediment in their clinical development for autoimmune diseases. Hypercalcemia develops as a result of the action of VDR agonists on the intestine. Here, we describe the identification of a VDR modulator (VDRM) compound A that was transcriptionally less active in intestinal cells and as a result exhibited less calcemic activity in vivo than 1,25- $(\mathrm{OH})_{2} \mathrm{D}_{3}$. Cytokine analysis indicated that the VDRM not only modulated the T-helper cell balance from Th1 to Th2 effector function but also inhibited Th17 differentiation. Finally, we demonstrate that the oral administration of compound A inhibited the induction and progress of experimental autoimmune encephalomyelitis in mice without causing hypercalcemia.
\end{abstract}

\section{Introduction}

Experimental autoimmune encephalomyelitis (EAE), an inflammatory demyelinating disease induced in mice by immunization with myelin components, displays pathological and clinical resemblances to the human demyelinating disease multiple sclerosis (MS). EAE and MS are characterized clinically by neurodegeneration and paralysis and pathologically by demyelination and infiltration of lymphocytes and monocytes into the CNS [1]. Epidemiological studies have shown a global north-south gradient of MS incidence and mortality rates. In other words, geographic distribution of MS prevalence increases with increasing latitude on both sides of the equator $[2,3]$. A strong correlation between latitude and MS incidence could be explained by the decreased exposure of susceptible population to UV radiation. Since UV light is required for vitamin D synthesis in the skin, a number of studies have explored the connection between vitamin D and MS. In a prospective epidemiological study (Nurses' Health Study) involving 187,000 women from 1980 to 2001, intake of vitamin D from supplements was inversely associated with the risk of MS [4]. The notion that vitamin $\mathrm{D}$ could be involved in the regulation of disease activity of MS is further strengthened from the observation that lower serum 25-hydroxyvitamin D levels were observed during MS relapses than those during remission [5]. Importantly, pharmacological doses of the biologically active form of vitamin D (1,25-dihydroxyvitamin D3; 1,25$\left.(\mathrm{OH})_{2} \mathrm{D}_{3}\right)$ greatly reduced the incidence of disease in the EAE model [6].

$1,25-(\mathrm{OH})_{2} \mathrm{D}_{3}$ is being increasingly recognized as an important immunomodulatory agent apart from its classical 
role in mineral homeostasis and maintenance of skeletal architecture. 1,25- $(\mathrm{OH})_{2} \mathrm{D}_{3}$ and its synthetic analogs exert these effects by binding to the vitamin $\mathrm{D}$ receptor (VDR) that belongs to the steroid/thyroid hormone nuclear receptor superfamily $[7,8]$. VDR, a ligand-dependent transcription factor, functions as a heterodimer with another nuclear receptor, namely, retinoid X receptor (RXR). Upon ligand binding, VDR undergoes a conformational change that promotes RXR-VDR heterodimerization [9, 10]. Liganded RXR-VDR heterodimer translocates to the nucleus, binds to the vitamin $\mathrm{D}$ responsive elements (VDREs) present in the promoter regions of responsive genes, and recruits chromatin modifying enzymatic activities through interaction with coactivators and DRIP complex, which ultimately leads to the initiation of transcription [11]. 1,25- $(\mathrm{OH})_{2} \mathrm{D}_{3}$ and its synthetic analogs act as immunomodulators with immunoregulatory and anti-inflammatory properties $[3,12$, 13 ] and as a result have shown efficacy in various in vitro and in vivo models of autoimmune diseases (arthritis, multiple sclerosis, inflammatory bowel disease, and EAE). However, the major hurdle facing the translation of basic and applied research to therapeutic ligands is hypercalcemia associated with the current generation of VDR ligands. Therefore, there is a clinical unmet need for the identification of novel VDR ligands that exhibit an improved therapeutic index.

$1,25-(\mathrm{OH})_{2} \mathrm{D}_{3}$ is a secosteroidal compound and most of the VDR ligands that have been described to date have a secosteroidal backbone [14]. Administration of VDR ligands results in hypercalcemia by increasing calcium absorption from the intestine. Consistent with this view, VDR-null mice display marked hypocalcemia [15]. 1,25- $(\mathrm{OH})_{2} \mathrm{D}_{3}$ action on duodenal enterocytes induces calcium transport protein $1 /$ transient receptor potential vanilloid epithelial calcium channel 6 (CaT1/TRPV6) expression, which channels calcium from the intestinal lumen into the cell [16]. VDR ligands also induce the expression of an EF-hand-containing carrier protein, calbindin-9k that ferries the bound calcium from the apical to the basolateral membrane [16]. Therefore, a tissue selective/cell-context-dependent VDR ligand that is transcriptionally less active in intestinal cells but a potent agonist in immune cells may exhibit reduced hypercalcemia liability and a better therapeutic index required for the treatment of MS. Since nonsteroidal structures have provided tissue selective estrogen receptor modulators (SERMs) that are agonists in bone and antagonists or transcriptionally inactive in breast and uterine cells $[17,18]$, we have identified and characterized a nonsecosteroidal analog of vitamin $\mathrm{D}$, compound $\mathrm{A}$, as a nonsecosteroidal VDRM. We demonstrate that compound $\mathrm{A}$ functions as a potent and efficacious agonist in human peripheral blood mononuclear cells (PBMCs) and osteoblasts but exhibits attenuated transcriptional activity in intestinal cells. In addition, compound A modulates the balance of Th1 versus Th2 cytokine profile. A plausible mechanism of this shift could be due to the induction of GATA3, a master regulator of Th2 differentiation. The cell-context-dependent activity of compound A also translated in vivo in reduced hypercalcemic liability in a murine model of hypercalcemia. We also demonstrate that in a preclinical murine EAE model of
MS, compound A delayed the onset of EAE and reduced the severity of the disease at a noncalcemic dose. Finally, splenocytes obtained from VDRM-treated MOG-induced EAE animals showed attenuated $\mathrm{T}$ cell proliferation response to the MOG peptide antigen and showed increased IL-10 and reduced interferon- $\gamma$ (IFN- $\gamma$ ) production. Furthermore, VDRM significantly inhibited Th17 differentiation. Thus, compound A represents a novel class of VDRMs that could be efficacious for treating autoimmune diseases such as MS without hypercalcemia side effect.

\section{Methods}

2.1. Cell Culture and Transfections. For the RXR-VDR heterodimerization assay, Saos-2, cells maintained in DMEM supplemented with $10 \%$ FBS were plated at 5000 cells/well in a 96-well plate. The next day, cells were transfected using $0.5 \mu \mathrm{L}$ of fugene (Roche Diagnostics, Indianapolis, IN), $100 \mathrm{ng}$ of luciferase reporter vector pFR-Luc (Stratagene, La Jolla, CA) and $10 \mathrm{ng}$ each of pVP16-VDR-LBD and pGal4RXR $\alpha$-LBD expression vectors/well. For HeLa and Caco2 one-hybrid mammalian transactivation assay, HeLa and Caco-2 cells, maintained in DMEM supplemented with 10\% FBS, were plated at 5000 cells/well in a 96-well plate. Cells were transfected using $0.5 \mu \mathrm{L}$ of fugene (Roche Diagnostics, Indianapolis, IN), $100 \mathrm{ng}$ of luciferase reporter vector $\mathrm{pFR}$ Luc (Stratagene, La Jolla, CA), and $10 \mathrm{ng}$ of pGal4-VDRLBD expression vectors/well. Total DNA amount was kept constant by adding empty vector DNA as needed. Cells were treated with the ligand 24 hours after-transfection, and luciferase activity was quantitated the next day using SteadyGlo luciferase detection reagent (Promega, Madison, WI).

2.2. Rat Osteocalcin Luciferase (OCN-Luc) Assay. The activation of osteocalcin VDRE by VDR ligands was evaluated in a rat osteoblast-like cell line (ROS 17/2.8) stably expressing rat osteocalcin promoter $(1.154 \mathrm{~kb})$ fused with luciferase reporter gene. The development of the stably transfected ROS 17/2.8 cell line (RG-15) containing OCNLuc has been described [19]. Confluent RG-15 cells maintained in DMEM/F-12 medium (3:1) containing 5\% FBS, $300 \mu \mathrm{g} / \mathrm{mL}$ G4 18 at $37^{\circ} \mathrm{C}$ were trypsinized $(0.25 \%$ trypsin) and plated into white opaque 96-well cell culture plates (25000 cells/well). After 24 hours, cells (in DMEM/F12 medium containing 2\% FBS) were treated with the indicated concentrations of the compounds. After 48 hours of treatment, the medium was removed, cells were lysed with $50 \mu \mathrm{L}$ of lysis buffer (from luciferase reporter assay system, Roche Diagnostics, Indianapolis, IN) and assayed for luciferase activity using the Luciferase Reporter Gene Assay kit from Roche Diagnostics. Aliquots $(20 \mu \mathrm{L})$ of cell lysates were pipetted into wells of white opaque microtiter plates (Dynex Technologies, Chantilly, VA) and placed in an automated injection MLX microtiter plate luminometer. The luciferase reaction mix $(100 \mu \mathrm{L})$ was injected sequentially into the wells. The light signals generated in the reactions were integrated over an interval of two seconds and the resulting luminescence values were used as a measure of luciferase activity (relative units). 
2.3. TRPV6 Quantitative RT-PCR (Q-PCR) Assay. Human colon carcinoma, Caco-2, cells, maintained in DMEM (high glucose with $25 \mathrm{mM}$ Hepes buffer; Invitrogen, Carlsbad, CA) supplemented with 10\% FBS (Invitrogen, Carlsbad, CA), were plated at 5500 cell per well in a 96-well plate in a total volume of $100 \mu \mathrm{L} /$ well. The cells were kept in the 96-well plate for 6 days to differentiate them into small intestinal cells that express TRPV6/CaT1. On day 3 after plating, spent media were removed and replaced with fresh media $(150 \mu \mathrm{L} /$ well). On day 6 , the spent media were removed again and the cells were maintained in treatment media (180 $\mu \mathrm{L} /$ well) (DMEM (low glucose, without phenol red; Invitrogen, Carlsbad, CA) containing 10\% charcoalstripped FBS (Hyclone, Logan, UT)). The cells were treated with various concentrations of VDR ligands prepared in treatment media $(20 \mu \mathrm{L} /$ well $)$. Twenty hours after-treatment, total RNA was prepared by the RNeasy 96 method, as described by the manufacturer (Qiagen, Valencia, CA). The RNA was reversetranscribed and amplified for human TRPV6 and GAPDH mRNAs by quantitative RT-PCR using the ABI PRISM 7900HT Sequence Detection System (Applied Biosystems, Foster City, CA). Optimized primer pairs and probes for human TRPV6 and GAPDH genes were obtained commercially (Applied Biosystems, Foster City, CA). Each $20 \mu \mathrm{L}$ quantitative RT-PCR reaction in a 384well Taqman PCR plate consisted of forward and reverse primers (900 nM), Taqman probe $(200 \mathrm{nM})$, total RNA $(4 \mu \mathrm{L}$ for each well of the 96-well culture plate), and $10 \mu \mathrm{L}$ of Taqman Universal PCR Master Mix (Roche Diagnostics, Indianapolis, IN). Reactions were incubated at $48^{\circ} \mathrm{C}$ for 30 minutes, followed by 10 minutes at $95^{\circ} \mathrm{C}$, and subjected to 40 cycles of PCR $\left(95^{\circ} \mathrm{C}\right.$ for 15 seconds followed by $60^{\circ} \mathrm{C}$ for 1 minute).

2.4. Cytokine Assays in PBMCs. Peripheral blood mononuclear cells (PBMCs) were isolated from normal human donors by sedimentation on Ficoll-Hypaque. Cells were resuspended in RPMI-1640 supplemented with charcoaltreated FBS $(2 \%)$. PBMCs $\left(25 \times 10^{6} /\right.$ T75 flask $)$ were treated with PHA $(10 \mu \mathrm{g} / \mathrm{mL})$ and TPA $(100 \mathrm{ng} / \mathrm{mL})$. The cells were cultured in the presence of various concentration of $1,25-(\mathrm{OH})_{2} \mathrm{D}_{3}$ or compound A prepared in RPMI-1640 containing $2 \%$ charcoal-treated FBS. Cytokine levels were quantitated by multiplex ELISA using antibodies specific for IL-4, IL-5, IL-13, and IFN- $\gamma$. Twenty four hours aftertreatment, total RNA was prepared by the RNeasy 96 method and the RNA was reversetranscribed and amplified for human IL-2, IFN- $\gamma$, IL-4, IL-10, GATA-3, and GAPDH mRNAs by quantitative RT-PCR as described in the TRPV6 Q-PCR assay section.

2.5. In Vivo Hypercalcemia Assay. Female, 6-7 weeks old, DBF1 mice, weighing $\sim 25 \mathrm{~g}$, were purchased from Harlan Industries (Indianapolis, IN). Mice were housed with ad libitum access to food (TD 5001 with $0.95 \%$ calcium and $0.67 \%$ phosphorus, vitamin D3 $4500 \mathrm{IU} / \mathrm{kg}$; Teklad, Madison, WI) and water. Compounds were given daily orally via gavage for 6 days. Dosing volume was $100 \mu \mathrm{L} /$ mouse with 4 mice in each group. Serum ionized calcium was examined at 6 hours after last dosing using a Ciba-Corning 634 $\mathrm{Ca}^{++} / \mathrm{pH}$ Analyzer (Chiron Diagnostics Corp., East Walpole, $\mathrm{MA})$.

2.6. EAE Model. All mice (C57B6) were age- and sexmatched (6- to 10-week-old females) at the start of experiments. Mice were immunized subcutaneously at two sites on the back with $300 \mu \mathrm{g}^{\mathrm{MOG}_{35-55}}$ peptide (MEVGWYRSPFSRVVHLYRNGK, Peptides International, Louisville, KY) emulsified in a total of $200 \mu \mathrm{L}$ Complete Freund's Adjuvant (CFA; Difco, Detroit, MI) containing $500 \mu \mathrm{g}$ M. tuberculosis H37 Ra (Difco) on days 0 and 7, supplemented with intraperitoneal injections of $500 \mathrm{ng}$ pertussis toxin (Calbiochem, San Diego, CA) on days 0 and 2. Clinical symptoms of EAE were scored daily by a blinded observer using the following scale: 0: no symptoms, 0.5: distal weak or spastic tail, 1: completely limp tail, 1.5: limp tail and hind limb weakness (feet slip through cage grill), 2.0: unilateral partial hind limb paralysis, 2.5: bilateral partial hind limb paralysis, 3.0: complete bilateral hind limb paralysis, 3.5: complete hind limb and unilateral partial forelimb paralysis, and 4.0: moribund or death. The data was recorded as the mean daily clinical score. MOG-immunized mice were administered orally with vehicle (sesame seed oil), 1,25$(\mathrm{OH})_{2} \mathrm{D}_{3}(0.5 \mu \mathrm{g} / \mathrm{kg} / \mathrm{d})$ or compound A $(10 \mu \mathrm{g} / \mathrm{kg} / \mathrm{d})$ for 21 days in a total volume of $200 \mu \mathrm{L}$.

2.7. Splenocyte Cell Culture and Proliferation Assay. Splenocyte cell suspensions were isolated from $\mathrm{MOG}_{35-55^{-}}$ immunized mice at day 28 by homogenizing spleens between frosted glass slides (Fisher, Pittsburgh, PA) and removing RBC with ACK lysing buffer (BioWhittaker, Walkersville, $\mathrm{MD})$. Pooled splenocytes of 6 individual mice from the same group were plated in triplicate in 96-well round bottom plate at $2 \times 10^{5}$ cells/well in $200 \mu \mathrm{L}$ complete RPMI 1640 medium (Invitrogen) supplemented with $2 \mathrm{mM} \mathrm{L}$ glutamine, $25 \mathrm{mM}$ HEPES, $100 \mathrm{U} / \mathrm{mL}$ penicillin, $100 \mu \mathrm{g} / \mathrm{mL}$ streptomycin, $5.5 \times 10^{-5} \mathrm{M} 2-\mathrm{ME}$, and 5\% FCS (all supplements from Invitrogen) containing either 0 and $80 \mu \mathrm{g} / \mathrm{mL}$ of $\mathrm{MOG}_{35-55}$ (Peptides International) or control OVA $323-339$ peptide (ISQAVHAAHAEINEAGR, Research Genetics, Inc., Huntsville, AL) and cultured at $37^{\circ} \mathrm{C}, 5 \% \mathrm{CO}_{2}$. Proliferation was measured by incorporation of $\left[{ }^{3} \mathrm{H}\right]$-methylthymidine $(1 \mu \mathrm{Ci} /$ well, ICN Radiochemicals, Irvine, CA) during the last $8 \mathrm{hr}$ of culture using a filtermate harvester (Packard Instrument Co., Downers Grove, IL) and a 1450 microbeta liquid scintillation counter (Pharmacia Biotech AB). Results were determined as mean \pm SE from triplicate cultures. Cytokine levels produced by cultured splenocytes or purified CD11c+ dendritic cells from splenocytes (Miltenyi Biotech.) from $\mathrm{MOG}_{35-55}$-immunized mice were analyzed by removing $100 \mu \mathrm{L}$ of cell culture supernatant per well after $60 \mathrm{~h}$ of culture as described above. Supernatants were filtered using Millipore plates (Cat \# Mabvnob) and stored at $-80^{\circ} \mathrm{C}$. Cytokines were analyzed with LINCOplex mouse cytokine kit (St. Charles, Miss).

2.8. Nä̈ve $C D 4^{+} T$ Cell Th17 Differentiation In Vitro. Naïve mouse $\mathrm{CD}^{+} \mathrm{T}$ cells were purified with AutoMACS and 


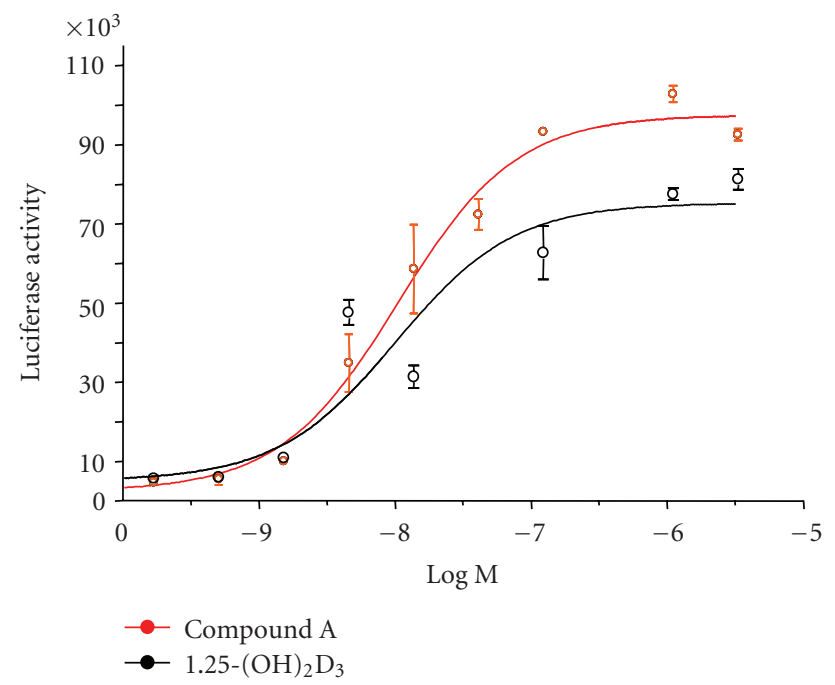

(a)

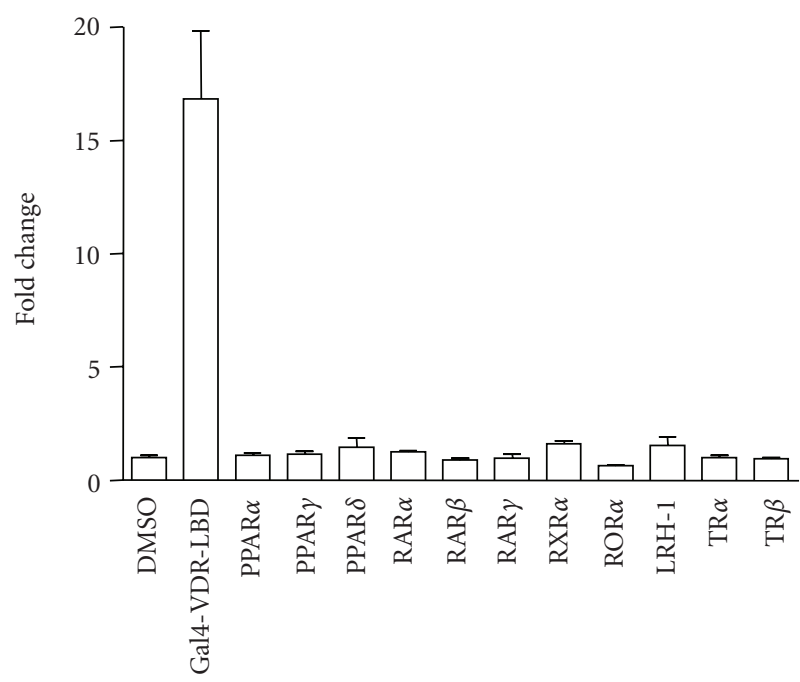

(b)

FIgURE 1: Compound A is a nonsecosteroidal VDR ligand. (a) Compound A is a potent agonist in RXR-VDR heterodimerization assay. SaOS-2 cells were cotransfected with expression vectors encoding Gal4-RXR $\alpha$-LBD and VP16-VDR-LBD along with a Gal4-responsive luciferase reporter. After transfection, cells were treated with vehicle or various concentrations of $1,25-(\mathrm{OH})_{2} \mathrm{D}_{3}$ or compound $\mathrm{A}$, and the reporter activity was expressed as light units \pm SE (standard error). A schematic of the RXR-VDR heterodimerization-based ligand-sensing assay and the chemical structures of $1,25-(\mathrm{OH})_{2} \mathrm{D}_{3}$ and compound A are also presented. (b) Compound A is selective for VDR-dependent transactivation. HeLa cells were cotransfected with various nuclear receptor-Gal4 DNA-binding domain chimeras and the reporter pFR-Luc. Cells were treated with $100 \mathrm{nM}$ compound A. Cell extracts were subsequently assayed for luciferase activity. Data are expressed for each receptor as fold induction of luciferase activity relative to vehicle-treated cells and represent the mean of four replicates \pm SE.

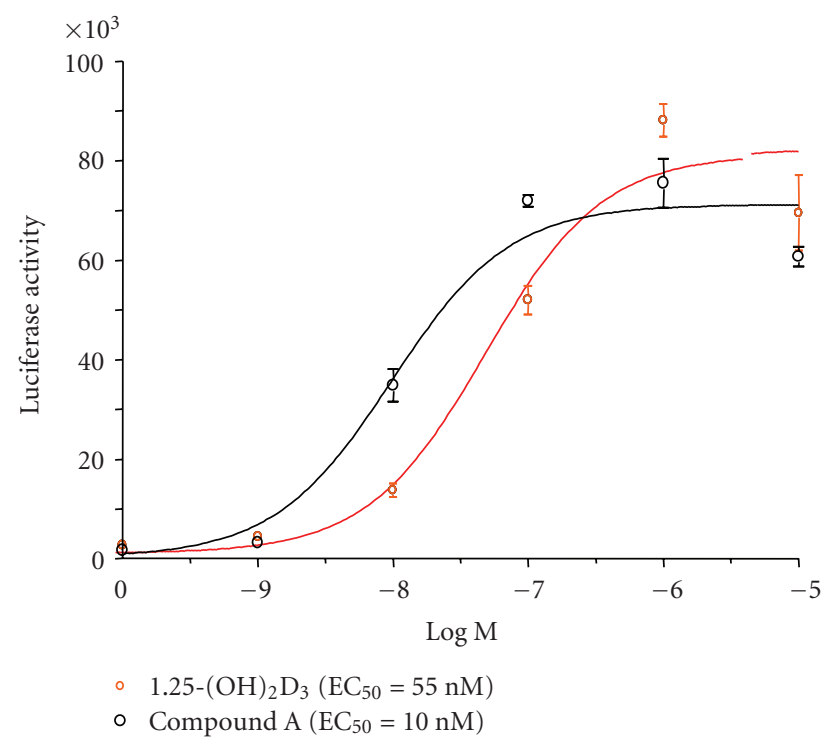

(a)

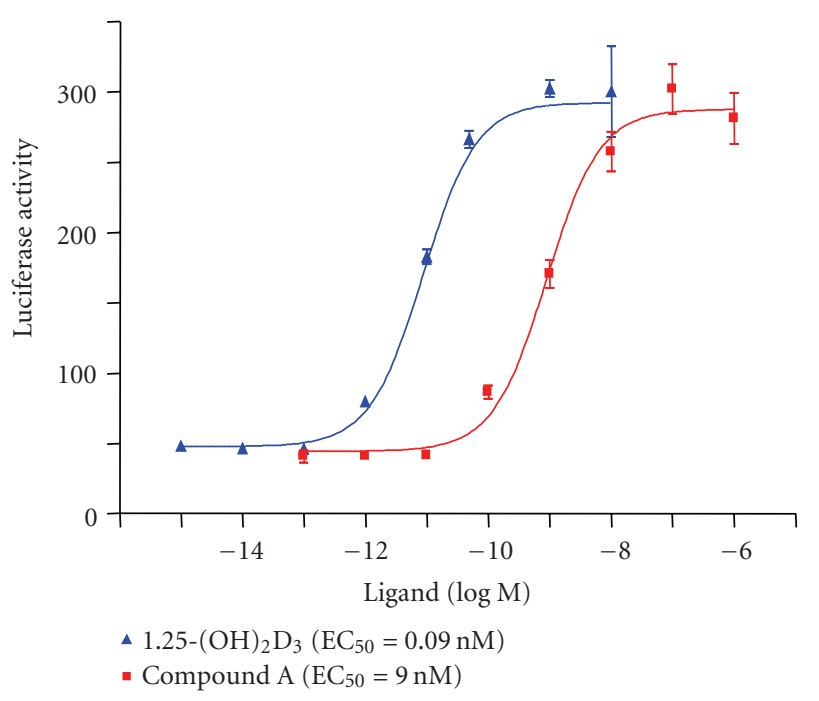

(b)

Figure 2: Compound A induces VDR-mediated gene expression. (a) Compound A is as potent as $1,25-(\mathrm{OH})_{2} \mathrm{D}_{3}$ in inducing VDR-LBDdependent gene expression. Luciferase activity $( \pm$ SE) of HeLa cells transfected with Gal4-VDR-LBD in a mammalian one-hybrid setting in the presence of vehicle or various concentrations of $1,25-(\mathrm{OH})_{2} \mathrm{D}_{3}$ or compound $\mathrm{A}$ is shown. Results are in arbitrary light units obtained from experiments performed in triplicate. (b) Compound A induces VDRE-dependent expression of the rat osteocalcin promoter in osteoblasts. ROS17/2.8 cells stably transfected with rat osteocalcin reporter (OCN-Luc) were treated with various concentrations of $1,25-(\mathrm{OH})_{2} \mathrm{D}_{3}$ or compound A. Results are shown in percentage of the luciferase activity obtained by treating the cells with $1 \mu \mathrm{M} 1,25-(\mathrm{OH})_{2} \mathrm{D}_{3}$. All the transfections were performed in triplicate. 


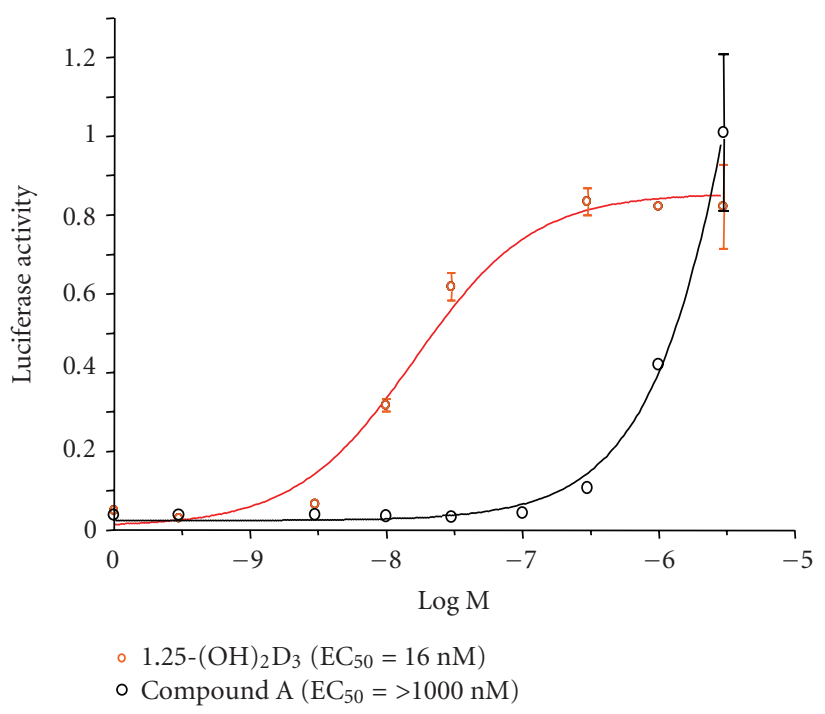

(a)

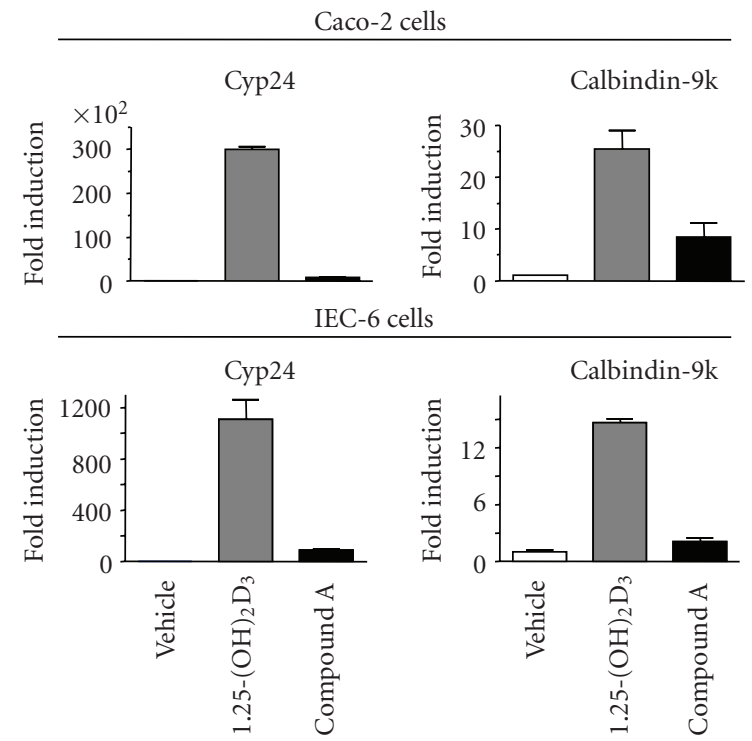

(b)

FIgURE 3: Compound A is less potent and efficacious in inducing the expression of vitamin D-responsive genes in intestinal cells. (a) Compound A shows weak potency in inducing the expression of endogenous CaT1 gene in differentiated Caco-2 cells. Taqman Q-PCR was performed on total RNA prepared from differentiated Caco- 2 cells treated with various concentrations of $1,25-(\mathrm{OH})_{2} \mathrm{D}_{3}$ or compound A for 24 hours. Levels of GAPDH mRNA were measured in all the samples, and the results were normalized and presented ( \pm SE) as relative light units (RLU) after normalization with the GAPDH transcript levels. (b) Compound A is a poor inducer of endogenous vitamin Dresponsive genes in differentiated Caco-2 and rat duodenal cells. Taqman Q-PCR was performed on total RNA prepared from Caco-2 and rat duodenal IEC-6 cells treated with vehicle or $100 \mathrm{nM}$ each of $1,25-(\mathrm{OH})_{2} \mathrm{D}_{3}$ or compound A for 24 hours. The fold induction of CYP24 and calbindin-9k transcripts relative to GAPDH transcripts is shown as mean \pm SE of quadruplicate experiments.

differentiated in vitro. To induce Th17 differentiation, $\mathrm{T}$ cells were incubated with plate-bound mAbs of anti-CD3 and anti-CD28 with soluble neutralizing mAbs of antiIL-4 $(5 \mu \mathrm{g} / \mathrm{mL})$, anti-IFN $\gamma(5 \mu \mathrm{g} / \mathrm{mL})$, recombinant IL-6 $(10 \mathrm{ng} / \mathrm{mL}), \mathrm{IL}-1 \beta(5 \mathrm{ng} / \mathrm{mL})$, and TGF- $\beta(5 \mathrm{ng} / \mathrm{mL})(\mathrm{R} \& \mathrm{D}$ System Inc., MN). Cells were then incubated at $37^{\circ} \mathrm{C}$ in the presence or absence of 1,25- $\left(\mathrm{OH}_{2}\right) \mathrm{D}_{3}$ and compound $\mathrm{A}$ for 4 days. Differentiated Th17 cells were then washed, and equal numbers of Th17 cells were restimulated with plate-bound anti-CD3 $\mathrm{mAb}$ for $18 \mathrm{~h}$ and cell supernatants were used for measuring levels of IL-17 and IL-22 by ELISA (R\&D System Inc. MN).

2.9. Statistical Analysis. Statistical significance versus control was defined as $P<.05$ in Dunnett's test. In vitro concentration-response curves were fit using the sigmoidal/variable slope fitting option in GraphPad Prism (GraphPad Software, Inc.).

\section{Results}

3.1. Compound A is a Nonsecosteroidal VDR Agonist. 1,25$(\mathrm{OH})_{2} \mathrm{D}_{3}$ and its synthetic analogs induce heterodimerization of VDR with RXR, resulting in the formation of RXR-VDR heterodimers that are the transcriptionally active functional units of vitamin D signaling pathway $[9,10,13]$. This assay is a surrogate for VDR ligand binding, since VDR ligands and not RXR ligands drive heterodimerization between RXR and VDR [10, 13]. The RXRVDR heterodimerization-based ligand sensing assay was performed by cotransfecting SaOS-2 cells with Gal4-RXR $\alpha$ LBD and VP16-VDR-LBD expression vectors, along with a Gal4-responsive reporter. 1,25- $(\mathrm{OH})_{2} \mathrm{D}_{3}$ and compound A were equipotent in inducing RXR-VDR heterodimerization with $\mathrm{EC}_{50}$ (concentration of the ligand required for $50 \%$ of the maximal activity) value of $10 \mathrm{nM}$ (Figure 1(a)). The receptor specificity of nonsecosteroidal VDR ligands was confirmed by transfecting SaOS-2 cells with the Gal4-DNA binding domain chimeras of various nuclear receptor-LBD constructs, along with a Gal4-responsive luciferase reporter. Compound A induced the expression of the Gal4-dependent reporter only through Gal4-VDR-LBD and not through Gal4-TR $\alpha$, Gal4-TR $\beta$, Gal4-RAR $\alpha$, Gal4-RAR $\beta$, Gal4-RAR $\gamma$, Gal4-PPAR $\alpha$, Gal4-PPAR $\delta$, Gal4-PPAR $\gamma$, Gal4-RXR $\alpha$, Gal4ROR $\alpha$, or Gal4-LRH1 LBDs (Figure 1(b)). The structures of compound A and its diaryl analogs have been reported in a US patent (no. 7772425).

To determine whether compound A also induces VDREdependent gene expression, a mammalian one-hybrid assay was performed in HeLa cells to compare the potencies of the VDR ligands in mediating Gal4-VDR-LBD-dependent transactivation of a Gal4-luciferase reporter construct. Both 1,25$(\mathrm{OH})_{2} \mathrm{D}_{3}$ and compound A were potent in inducing VDRLBD-mediated transactivation with $\mathrm{EC}_{50}$ values of 55 and $10 \mathrm{nM}$, respectively (Figure 2(a)). To further confirm that 


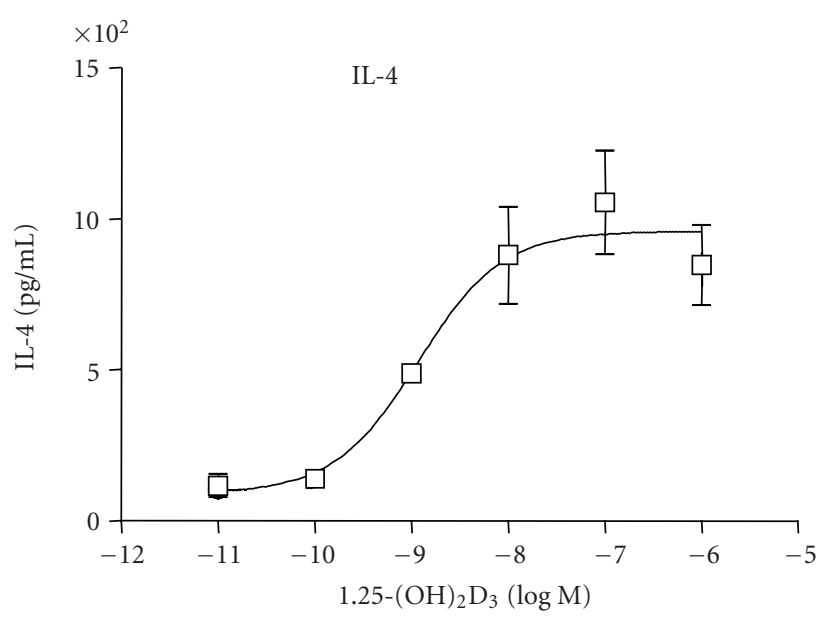

(a)

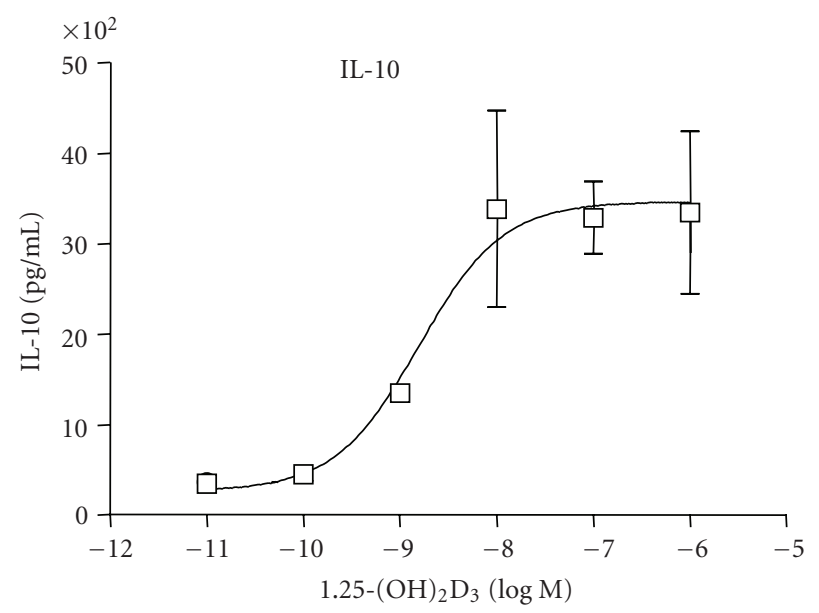

(c)

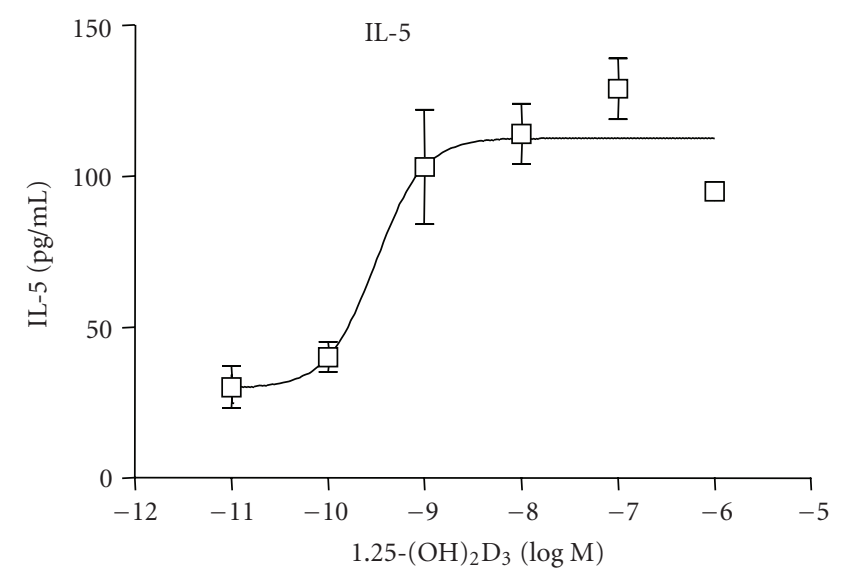

(b)

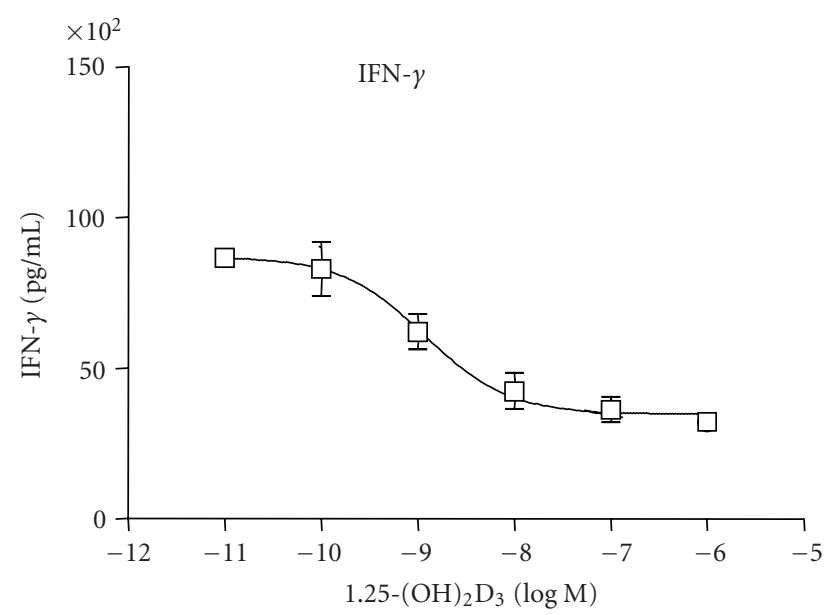

(d)

FIgURE 4: 1,25- $(\mathrm{OH})_{2} \mathrm{D}_{3}$ shifts the balance from Th1 to Th2 cells in activated PBMCs. Primary cells isolated from donors were stimulated with TPA $(100 \mathrm{ng} / \mathrm{mL})$ and PHA $(25 \mu \mathrm{L} / \mathrm{mL})$ and treated with vehicle or various concentrations of $1,25-(\mathrm{OH})_{2} \mathrm{D}_{3}$ for 24 hours. Cytokines were measured by LINCOplex human cytokine kit on supernatants obtained from vehicle-treated or VDR ligand-treated samples using antibodies for human IL-4, IL-5, IL-10, and IFN- $\gamma$. The amount of IL-4, IL-5, IL-10, and IFN- $\gamma$ protein levels is shown as mean \pm SE of triplicate experiments.

compound A was potent in inducing VDRE-dependent gene expression of an endogenous gene, Ros 17.2 rat osteosarcoma cells permanently transfected with a rat osteocalcin promoter luciferase reporter, OCN-Luc (15) were used. 1,25- $(\mathrm{OH})_{2} \mathrm{D}_{3}$ and compound $\mathrm{A}$ induced the expression of the rat $\mathrm{OCN}$ Luc reporter with $\mathrm{EC}_{50}$ values of 0.09 and $9 \mathrm{nM}$, respectively (Figure 2(b)).

3.2. Compound A Is a Less Potent Agonist than $1,25-(\mathrm{OH})_{2} \mathrm{D}_{3}$ in Intestinal Cells. VDR ligands result in hypercalcemia by increasing calcium absorption from the intestine. 1,25$(\mathrm{OH})_{2} \mathrm{D}_{3}$ has been shown to induce the expression of epithelial calcium channel, TRPV6, that absorbs calcium from the intestinal lumen into the duodenal enterocyte $[15,16]$. TRPV6 is a vitamin D-responsive gene in vitro and in vivo, and its expression is drastically reduced in VDR knockout mice $[15,16,20]$. Therefore, a cell-context-dependent VDR ligand that is transcriptionally less active in intestinal cells but a potent agonist in target cells (immune cell) may exhibit reduced hypercalcemic liability. We next examined the expression of endogenous TRPV6 gene in Caco-2 cells after treatment with VDR ligands. Although Caco-2 cells are colon cancer cells, upon density-dependent growth (6-14 days of culture), they differentiate into small intestinal like cells that express many of the markers of small intestine, including TRPV6, which is normally expressed in the duodenum [20]. These cells upon differentiation also acquire the machinery required for VDR ligand-dependent transepithelial calcium transport (apical to basolateral), similar to that of enterocytes $[20,21] .1,25-(\mathrm{OH})_{2} \mathrm{D}_{3}\left(\mathrm{EC}_{50}=16 \mathrm{nM}\right)$ was a potent inducer of TRPV6 message in differentiated Caco-2 cells (Figure 3(a)). In contrast, compound A $(\mathrm{EC} 50=>1000 \mathrm{nM})$ showed attenuated potency in inducing the expression of the endogenous TRPV6 gene in differentiated Caco-2 cells 


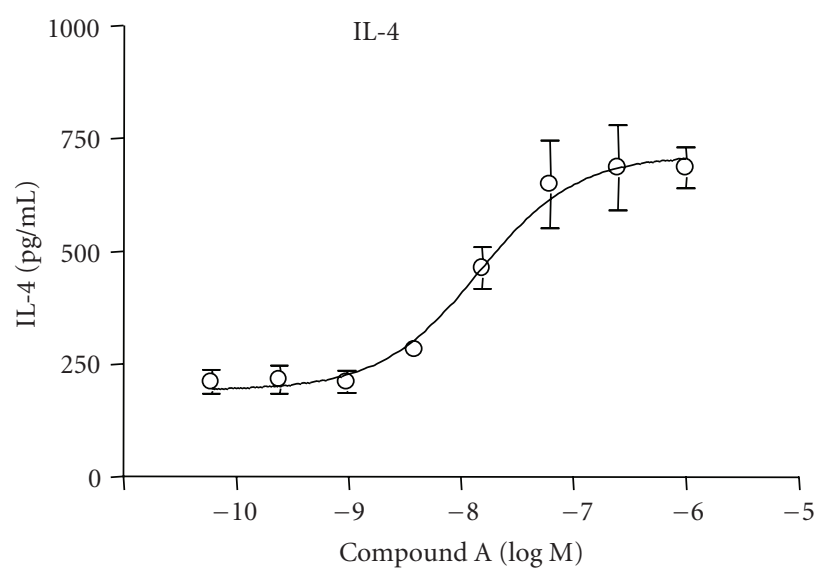

(a)

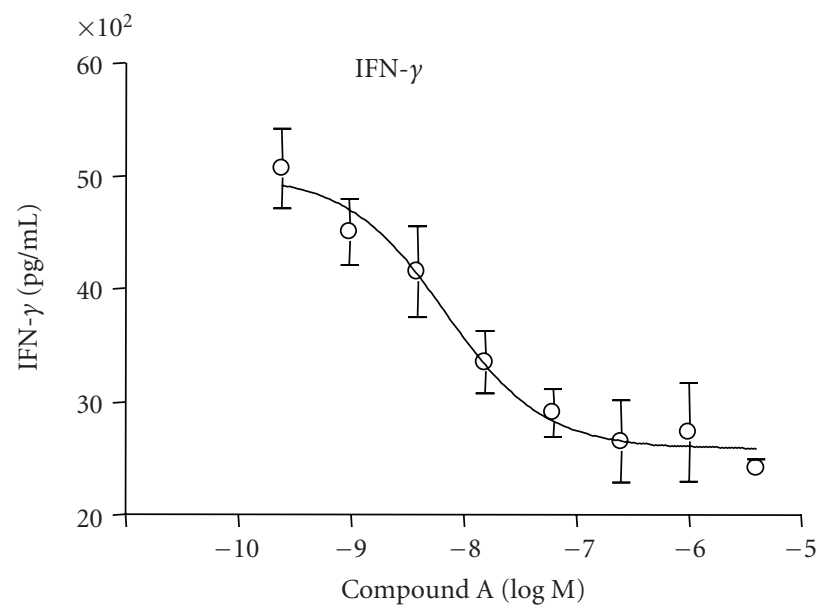

(c)

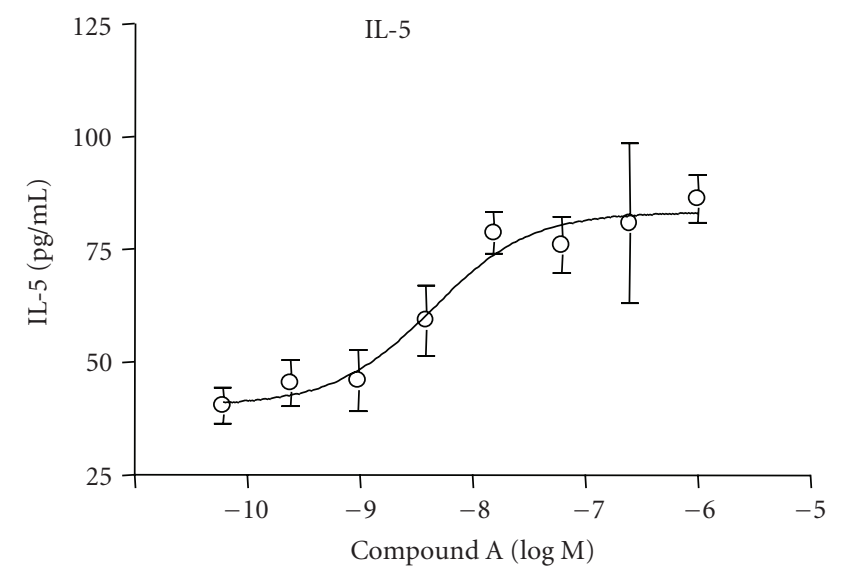

(b)

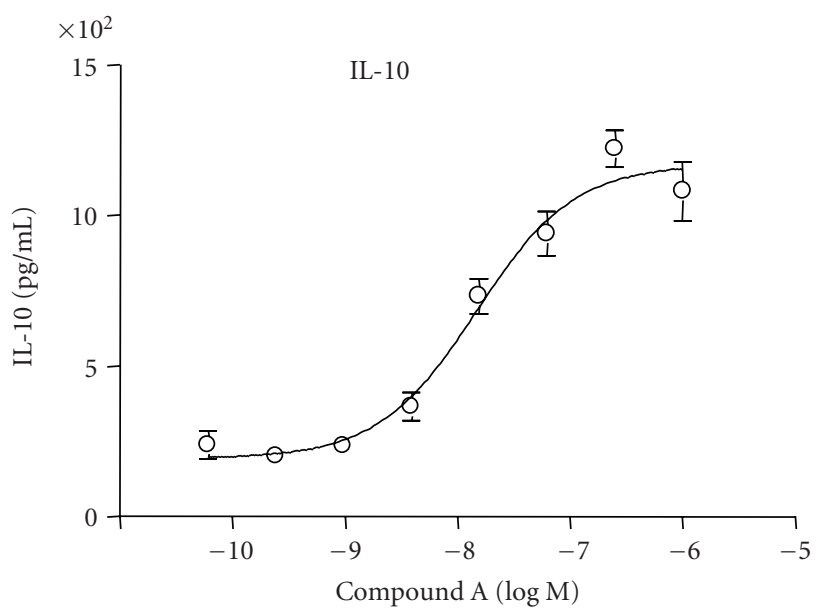

(d)

Figure 5: Compound A augments Th2 and inhibits Th1 cytokines in activated PBMCs. Primary cells isolated from donors were stimulated with TPA $(100 \mathrm{ng} / \mathrm{mL})$ and PHA $(25 \mu \mathrm{L} / \mathrm{mL})$ and treated with vehicle or various concentrations of compound A for 24 hours. Cytokines were measured by LINCOplex human cytokine kit on supernatants obtained from vehicle-treated or VDR ligand-treated samples using antibodies for human IL-4, IL-5, IL-10, and IFN- $\gamma$. The amount of IL-4, IL-5, IL-10, and IFN- $\gamma$ protein levels is shown as mean \pm SE of triplicate experiments.

(Figure 3(a)). These results indicate the cell-type selectivity of compound A since it was less potent than $1,25-(\mathrm{OH})_{2} \mathrm{D}_{3}$ in Caco-2 cells.

We also compared compound A with $1,25-(\mathrm{OH})_{2} \mathrm{D}_{3}$ for its effect on the expression of two VDRE-dependent genes, namely, CYP24 and calbindin-9k in differentiated Caco-2 and IEC-6 (rat duodenal crypt cell line) cells. Treatment of Caco-2 and IEC-6 cells with $1,25-(\mathrm{OH})_{2} \mathrm{D}_{3}(100 \mathrm{nM})$ for 24 hours resulted in a robust induction of human and rat CYP24 and calbindin-9k gene expression (Figure 3(b)). In contrast, compound A was significantly less efficacious than $1,25-(\mathrm{OH})_{2} \mathrm{D}_{3}$ in inducing the expression of endogenous CYP24 and calbindin-9k in these cells (Figure 3(b)). All these observations further support the notion that compound $\mathrm{A}$ is a cell-context-dependent VDRM.

3.3. Compound A Is a Potent Agonist in PBMCs. The lesions of Multiple Sclerosis have shown an increased expression of proinflammatory Th1 cytokines and decreased expression of Th2 anti-inflammatory cytokines IL-4 and IL-10. The disease is also ameliorated by IL- 4 and IL-10 cytokine therapy in an EAE murine model of multiple sclerosis $[20,22] .1,25-(\mathrm{OH})_{2} \mathrm{D}_{3}$ affects the Th1-Th2 balance, and it has been shown to augment Th2 cell development which is accompanied by increased production of IL- 4 and IL-10 cytokines in vitro and in vivo $[8,13,23,24]$. The effect of $1,25-(\mathrm{OH})_{2} \mathrm{D}_{3}$ and compound $\mathrm{A}$ on cytokine secretion from PHA/PMA-activated human PBMCs was examined by multiplex ELISA. $1,25-(\mathrm{OH})_{2} \mathrm{D}_{3}$ increased IL-10 protein levels in PHA/PMA-activated human PBMCs with an $\mathrm{EC}_{50}$ value of $2 \mathrm{nM}$ (Figure 4). Compound A also increased IL-10 cytokine levels and showed $\mathrm{EC}_{50}$ value of $14 \mathrm{nM}$ (Figure 5). Both 1,25- $(\mathrm{OH})_{2} \mathrm{D}_{3}$ and compound $\mathrm{A}$ induced the protein levels of Th2 cytokines IL-4, IL-5, and IL-10 in a dosedependent manner (Figures 4 and 5). However, the levels of Th1 cytokine IFN $\gamma$ were decreased in a dose-responsive 


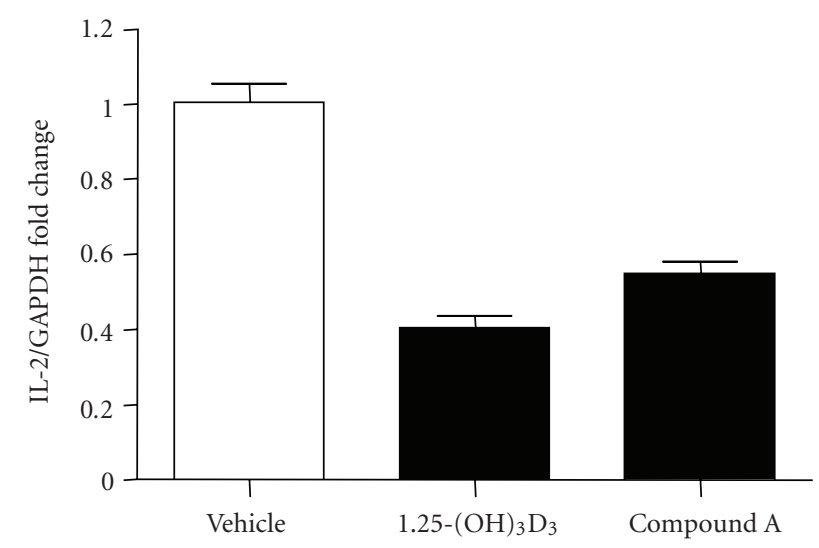

(a)

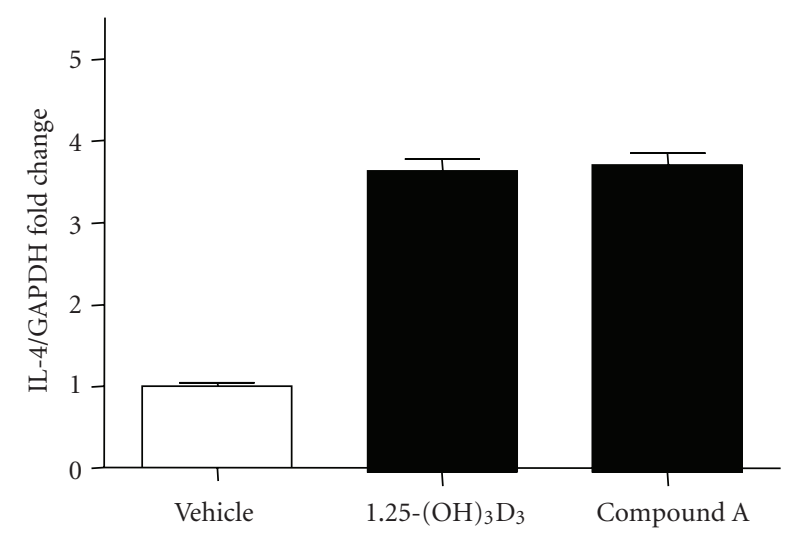

(c)

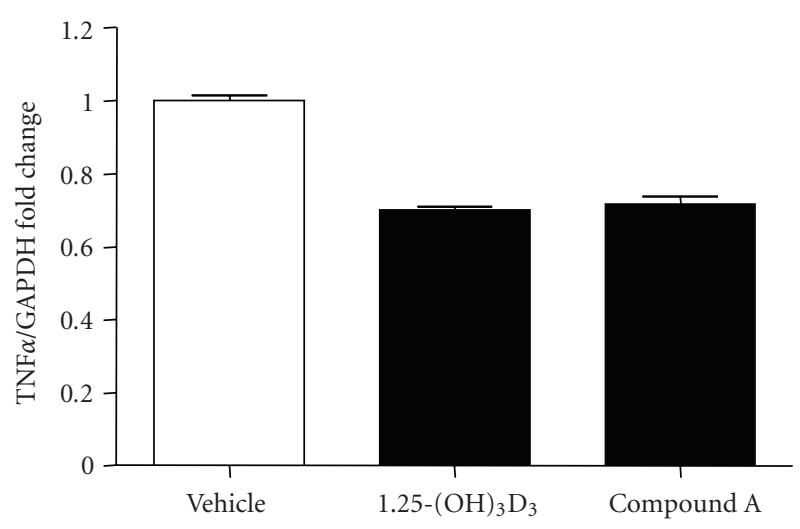

(e)

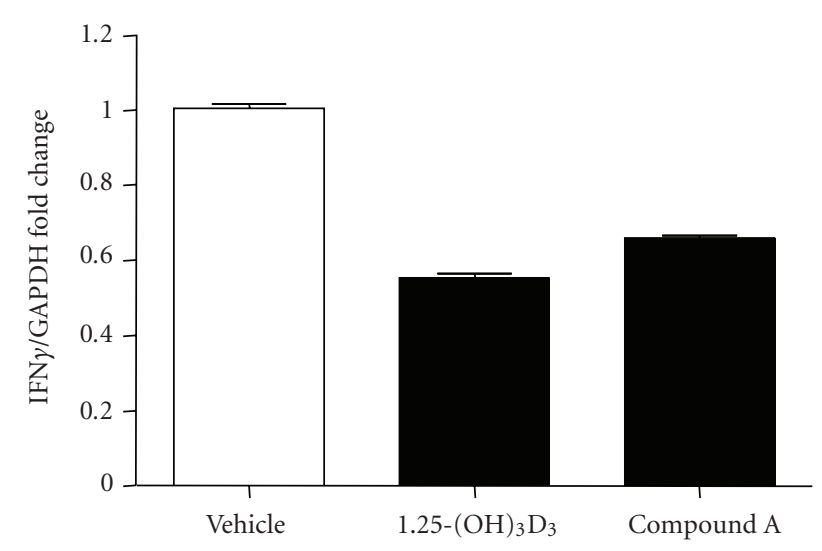

(b)

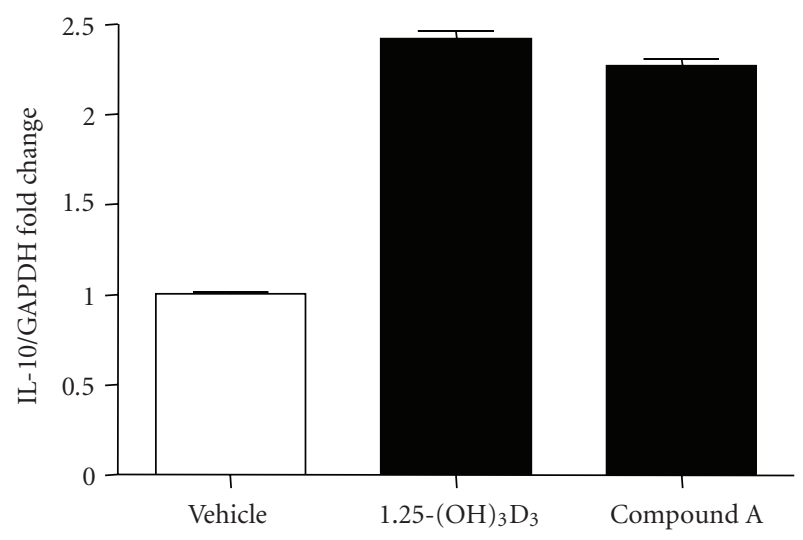

(d)

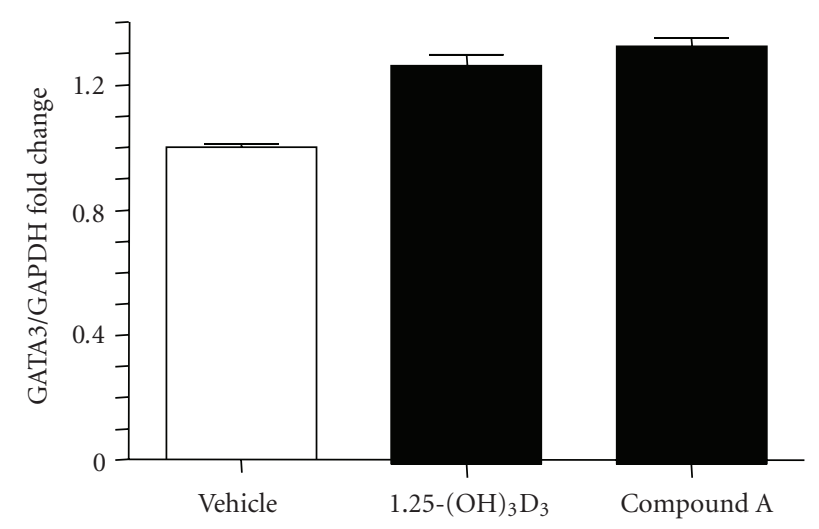

(f)

Figure 6: Nonsecosteroidal VDRM is as efficacious as $1,25-(\mathrm{OH})_{2} \mathrm{D}_{3}$ in modulating cytokine gene expression in activated human PBMCs. Primary cells isolated from donors were stimulated with TPA $(100 \mathrm{ng} / \mathrm{mL})$ and PHA $(25 \mu \mathrm{L} / \mathrm{mL})$ and treated with vehicle or $100 \mathrm{nM}$ each of $1,25-(\mathrm{OH})_{2} \mathrm{D}_{3}$ and compound A for 24 hours. Taqman Q-PCR was performed on RNA obtained form vehicle-treated or VDR ligand-treated samples using primer pairs and probes for IL-2, IL-4, IL-10, IFN- $\gamma$, TNF- $\alpha$, GATA3, and GAPDH. The amount of IL-2, IL-4, IL-10, IFN- $\gamma$, TNF- $\alpha$, and GATA3 transcripts relative to GAPDH transcripts is shown as mean \pm SE of quadruplicate experiments.

manner after $1,25-(\mathrm{OH})_{2} \mathrm{D}_{3}$ and compound $\mathrm{A}$ treatments (Figures 4 and 5). The $\mathrm{EC}_{50}$ values for IL-4, IL-5, and IL10 induction and IFN $\gamma$ inhibition were $1 \mathrm{nM}, 0.3 \mathrm{nM}, 2 \mathrm{nM}$, and $1 \mathrm{nM}$, respectively for $1,25-(\mathrm{OH})_{2} \mathrm{D}_{3}$. The corresponding $\mathrm{EC}_{50}$ values for compound A were $14 \mathrm{nM}, 4 \mathrm{nM}, 7 \mathrm{nM}$, and $14 \mathrm{nM}$, respectively (Figures 4 and 5). These results indicate that compound A is not only a potent agonist in PBMCs but also shifts the balance from proinflammatory Th1 to antiinflammatory Th2 phenotype.

Furthermore, 1,25- $(\mathrm{OH})_{2} \mathrm{D}_{3}$ and compound A were equally efficacious in decreasing the mRNA expression of Th1 cytokines IL- 2 and IFN- $\gamma$ and increasing the mRNA expression of Th2 cytokines IL-4 and IL-10 in activated PBMCs (Figure 6). In addition, the VDR ligands showed 


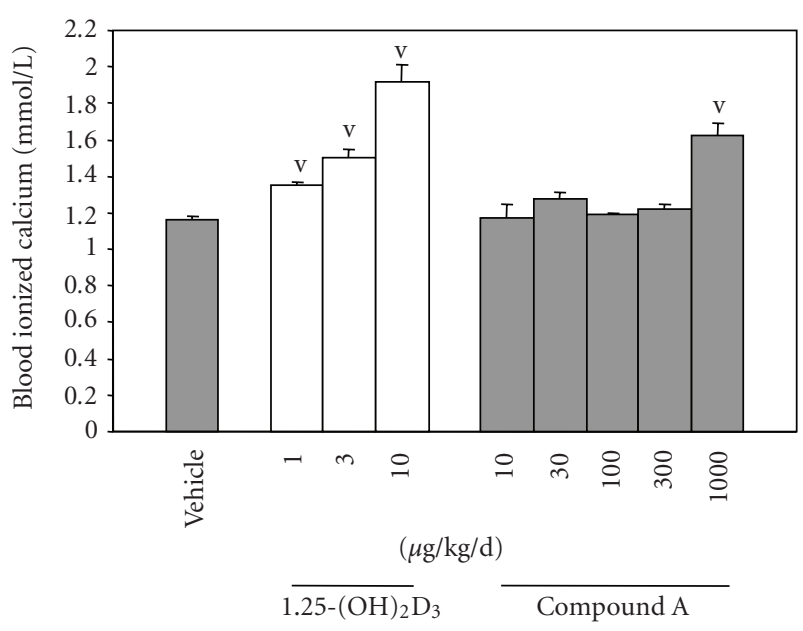

Figure 7: Compound $\mathrm{A}$ is less calcemic in vivo. $1,25-(\mathrm{OH})_{2} \mathrm{D}_{3}$ or compound A was administered in sesame seed oil at indicated doses to mice by gavage for 6 consecutive days, and blood ionized calcium was measured 6 hours after the last dose.

equivalent efficacy for decreasing TNF- $\alpha$ expression in activated PBMCs (Figure 6). 1,25- $(\mathrm{OH})_{2} \mathrm{D}_{3}$ has also been shown to induce the expression of GATA-3 [13], a master regulator of Th2 differentiation [24]. Interestingly, compound A was also as efficacious as $1,25-(\mathrm{OH})_{2} \mathrm{D}_{3}$ in augmenting GATA3 expression (Figure 6). Therefore, one of the plausible mechanisms of VDR ligand-mediated Th1 to Th2 shift might be their ability to induce the expression of basic helix-loophelix transcription factor GATA-3. Therefore, compound A exhibited similar immunomodulatory effects as 1,25 $(\mathrm{OH})_{2} \mathrm{D}_{3}$ in effector $\mathrm{T}$ cell functions.

3.4. Compound A Is Less Calcemic In Vivo. The hypothesis that the decreased VDR-mediated transcriptional activity of compound A on TRPV6 gene expression in differentiated Caco-2 cells would translate to less calcemic activity in vivo was tested after oral administration of VDR ligands to mice in a 6-day murine model of hypercalcemia. Mice were treated for 5 days with the VDR ligands, and bloodionized calcium was measured 24 hours after the last dosing. $1,25-(\mathrm{OH})_{2} \mathrm{D}_{3}$ caused hypercalcemia in mice when dosed at $1 \mu \mathrm{g} / \mathrm{kg} / \mathrm{d}$. In contrast, compound A showed statistically significant hypercalcemia only at $1000 \mu \mathrm{g} / \mathrm{kg} / \mathrm{d}$ but not at $300 \mu \mathrm{g} / \mathrm{kg} / \mathrm{d}$ dose (Figure 7). Therefore, compound $\mathrm{A}$ is at least 300 times less calcemic than $1,25-(\mathrm{OH})_{2} \mathrm{D}_{3}$ in vivo when administered orally.

\subsection{Compound A Inhibits Mouse EAE Induction and Severity} In Vivo. Since $1,25-(\mathrm{OH})_{2} \mathrm{D}_{3}$ and its secosteroidal analogs have shown efficacy in a number of murine autoimmune disease models, including EAE [6, 25-27], we next examined whether oral administration of compound A could also affect the pathogenesis of EAE without inducing hypercalcemia. EAE was induced in C57B6 mice by immunization with MOG peptide and the animals were dosed orally with 1,25$(\mathrm{OH})_{2} \mathrm{D}_{3}(0.05 \mu \mathrm{g} / \mathrm{kg} / \mathrm{d})$ or compound A $(10 \mu \mathrm{g} / \mathrm{kg} / \mathrm{d})$ daily for 21 days starting on the day of immunization. Vehicle control mice were immunized with MOG to induce the disease, and they were treated with vehicle (sesame seed oil). CFA control mice were mock immunized with CFA without MOG peptide and were not treated with vehicle or VDR ligands. Both $1,25-(\mathrm{OH})_{2} \mathrm{D}_{3}$ and compound A delayed the appearance of clinical signs of EAE induced by the MOG peptide. $1,25-(\mathrm{OH})_{2} \mathrm{D}_{3}$ initially reduced the severity of the disease until day 17 of the treatment. However, after day 19 , the severity of EAE in $1,25-(\mathrm{OH})_{2} \mathrm{D}_{3}$ treated group was indistinguishable from the control groups (Figure 8(a)). In contrast, compound A treatment significantly resulted in less severe course of disease throughout the treatment period (Figure 8(a)). Microscopic evaluation of spinal cord neuropathology revealed that compound A treatment prevented demyelination that was readily visible as demyelinated plaques containing infiltrating mononuclear cells in the spinal cord sections of vehicle-treated sample (Figure 8(b)). Demyelinated areas were reduced in the spinal cord sections of compound A-treated animals (Figure 8(b)). Since the major problem associated with $1,25-(\mathrm{OH})_{2} \mathrm{D}_{3}$ treatment is hypercalcemia, we also measured serum calcium levels at the end of the study. $1,25-(\mathrm{OH})_{2} \mathrm{D}_{3}(0.05 \mu \mathrm{g} / \mathrm{kg} / \mathrm{d})$ resulted in hypercalcemia whereas serum calcium levels were within the normal range after compound A $(10 \mu \mathrm{g} / \mathrm{kg} / \mathrm{d})$ treatment. The difference of serum $\mathrm{Ca}^{++}$level between 1,25$(\mathrm{OH})_{2} \mathrm{D}_{3}$-and compound A-treated animals was statistically different whereas there was no statistically difference between compound A and vehicle group (Figure 8(c)).

To determine if compound A can modulate antigen $\mathrm{T}$ cell function in EAE, total splenocytes from diseased mice were stimulated ex vivo with either MOG peptide or ovalbumin peptide at the indicated concentrations, and $\mathrm{T}$ cell proliferation was measured by ${ }^{3} \mathrm{H}$-thymidine incorporation. Compared with vehicle-treated mice, in vivo treatment with compound A suppressed the specific recall response to the encephalitogenic MOG peptide used in the EAE model (Figure 9(a)). The recall response of MOG-immunized animals was specific for the MOG peptide and was not observed for ovalbumin (OVA) peptide (Figure 9(a)). Furthermore, both $1,25-(\mathrm{OH})_{2} \mathrm{D}_{3}$ and compound A decreased Th1 cytokine IFN- $\gamma$ production in MOG-stimulated splenocytes (Figure 9(b)). Interestingly, both $1,25-(\mathrm{OH})_{2} \mathrm{D}_{3}$ and compound $\mathrm{A}$ also induced IL10 cytokine production in isolated $\mathrm{CD}_{11 \mathrm{c}^{+}}$dendritic cells stimulated with $100 \mathrm{ng} / \mathrm{mL}$ LPS (Figure 9(b)), indicating that compound A modulated immune response in vivo in autoimmune pathogenic conditions. Th17 cells have recently been demonstrated to be the essential pathogenic cells involved in EAE model. In order to test whether 1,25$(\mathrm{OH})_{2} \mathrm{D}_{3}$ and compound $\mathrm{A}$ had the direct effect on Th17 differentiation or Th17 secretion, we performed Th17 differentiation assay in vitro in the presence of these compounds. As shown in Figure 10, both $1,25-(\mathrm{OH})_{2} \mathrm{D}_{3}$ and compound A significantly inhibited both IL-17 and IL-22 expression, indicating that Th17 differentiation was efficiently inhibited by these compounds. Interestingly, once Th17 cells were fully differentiated, the restimulation of these differentiated Th17 cells by anti-CD3 mAb to produce IL-17 and IL-22 was only slighly affected by these compounds (data not shown), 


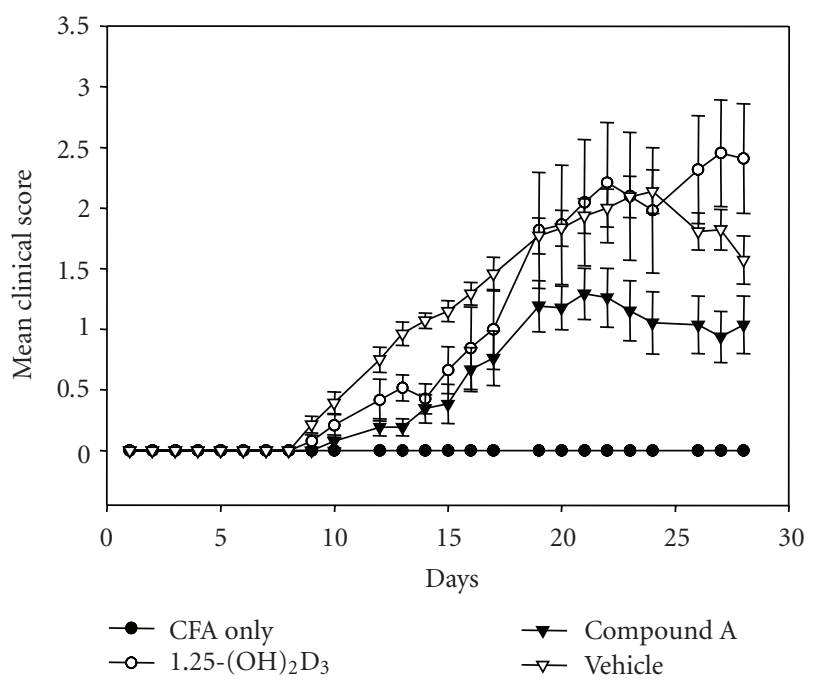

(a)

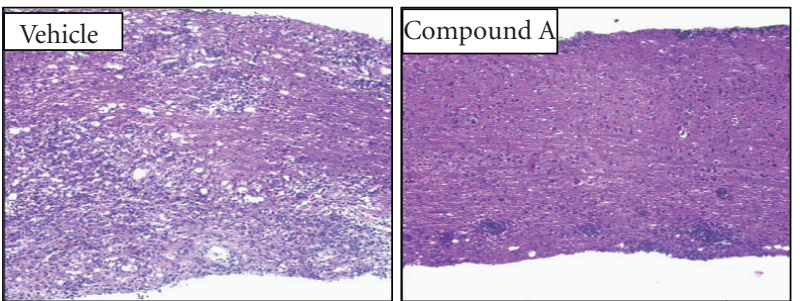

(b)

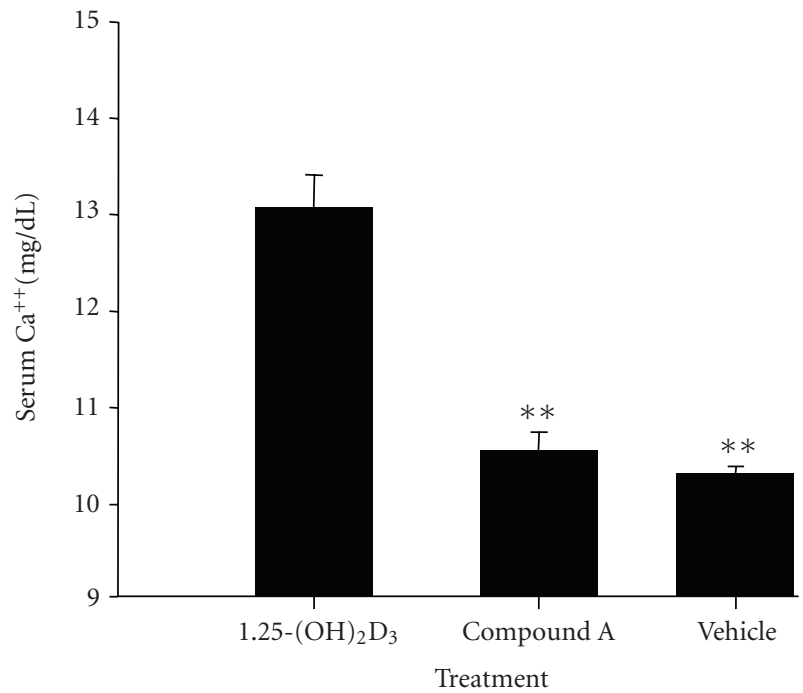

(c)

FIgURE 8: Oral administration of VDRM is therapeutically efficacious in MOG-induced EAE. (a) Clinical course of EAE after treatment with VDR ligands. MOG immunized C57B6 mice were orally administered with vehicle, $1,25-(\mathrm{OH})_{2} \mathrm{D}_{3}(0.5 \mu \mathrm{g} / \mathrm{kg} / \mathrm{d})$, or compound A $(10 \mu \mathrm{g} / \mathrm{kg} / \mathrm{d})$ for 21 days. Each point represents the mean clinical score for particular day in vehicle or VDR ligand-treated $(n=15)$ groups. Error bars represent mean \pm SE. Vehicle group consisted of MOG-immunized mice treated with vehicle (sesame seed oil). CFA group was mock immunized with CFA only (without MOG peptide) and was not treated with any ligands. There was statistically significant reduction of overall EAE disease score between the compound A-treated group and vehicle group and between compound A-treated and $1,25-(\mathrm{OH})_{2} \mathrm{D}_{3}$ treated group $(P<.001)$ whereas the difference between $1,25-(\mathrm{OH})_{2} \mathrm{D}_{3}$-treated group and vehicle group is nonsignificant. (b) Compound A improves spinal cord pathology in EAE. On day 28, mice spinal cords were harvested and subjected to histological analysis. Spinal cord sections of vehicle and compound A-treated MOG-immunized mice were analyzed for demyelination by eosin-hematoxylin staining. (c) Compound A does not cause hypercalcemia at therapeutically efficacious dose. At the end of the EAE study, blood ionized calcium was measured 6 hours after the last dose. Value shown represents mean values \pm SD of 15, 12, and 6 individual mice of vehicle group, compound A group, and 1,25- $(\mathrm{OH})_{2} \mathrm{D}_{3}$-treated group, respectively; ${ }^{* *} P<.01$.

indicating that VDRMs were mainly involved in Th17 differentiation stage.

\section{Discussion}

The success of nonsteroidal SERMs in limiting the side effects of estrogen on breast and uterus while still retaining therapeutic efficacy in bone [17] prompted us to pursue identification of nonsecosteroidal VDRMs for the treatment of autoimmune diseases, such as MS. In this study, we have identified a cell-context-dependent VDRM that shows attenuated calcemic liability in vivo relative to 1,25 $(\mathrm{OH})_{2} \mathrm{D}_{3}$. We also show that the nonsecosteroidal VDRM modulates the balance between Th1 and Th2 cells as well 

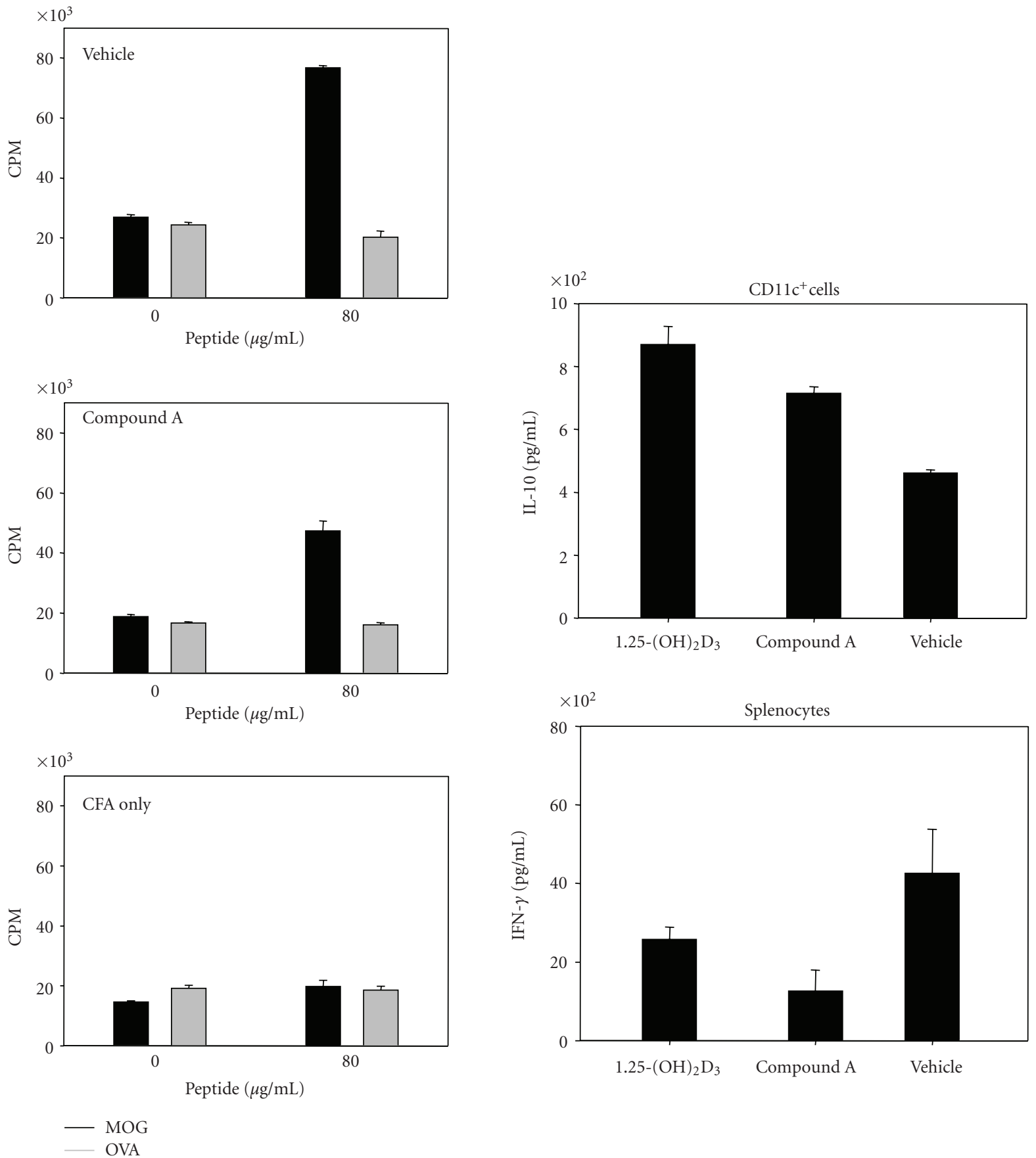

(a)

(b) Treatment

FIGURE 9: VDR ligands modulate peptide-specific recall responses from MOG-immunized mice. (a) Compound A inhibits the proliferation of MOG-specific splenocytes. Splenocytes from groups $(n=5)$ of MOG-immunized mice were harvested at day 28 and analyzed ex vivo for proliferative responses to MOG at the concentrations indicated. Cells were cultured in triplicate in 96-well plates for 60 hours, and proliferation was measured by ${ }^{3} \mathrm{H}$-thymidine incorporation during the final 8 hours of culture. Values represent the mean \pm SE of triplicate for each peptide concentration. Ovalbumin (OVA) peptide was used as specificity control since the mice were immunized with MOG peptide. Vehicle group consisted of MOG immunized mice treated with vehicle (sesame seed oil). CFA group was mock immunized with CFA only (without MOG peptide) and was not treated with any ligands. (b) Effect of VDR ligands on cytokine elaboration in MOG-immunized animals. For dendritic cell IL-10 production, CD11 $\mathrm{c}^{+}$cells were purified on day 28 from splenocytes obtained from MOG-immunized animals. The effect of VDR ligands on IL-10 levels from splenic CD11c cultures stimulated for 24 hours with $100 \mathrm{ng} / \mathrm{mL}$ LPS is shown. VDR ligands decreased IFN- $\gamma$ elaboration from splenocyte cultures stimulated for 48 hours with $80 \mu \mathrm{g} / \mathrm{mL}$ MOG peptide. IL-10 and IFN- $\gamma$ protein levels were measured by ELISA. 


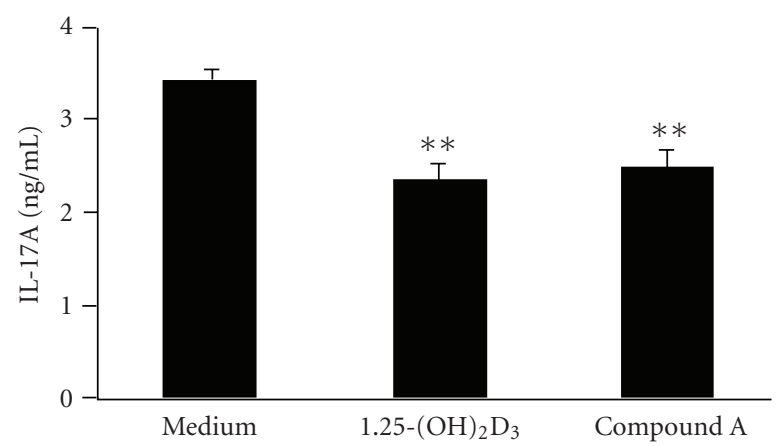

(a)

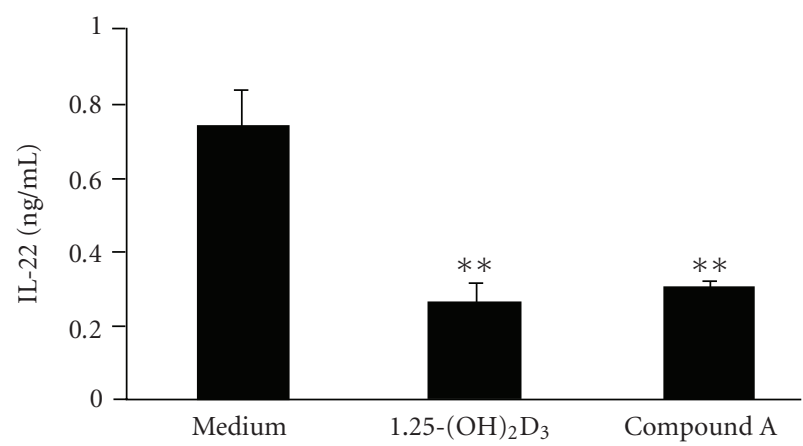

(b)

FIgURE 10: VDRM inhibits Th17 differentiation in vitro. Purified mouse naïve CD4+T cells were differentiated into Th17 cells in vitro under Th17 differentiation conditions for 4 days in the presence or absence of VDR ligands. Differentiated Th17 cells were then washed and restimulated with plate bound anti-CD3 mAb for $18 \mathrm{~h}$. The supernatant was then measured for the expression of IL-17 (a) and Il-22 (b) by ELISA. Value shown represent the mean values of triplicate cultures and error bars represent the standard deviation $(* * P<.01$.

as Th17 differentiation, since compound A inhibited Th1, Th17 cytokine production and augmented the production of Th2 cytokines. Furthermore, the nonsecosteroidal ligand described herein also displayed therapeutic activity in the EAE model at a nonhypercalcemic dose. Our results extend the observations that VDR ligands are efficacious in the treatment of murine EAE and demonstrate for the first time that a nonsecosteroidal VDRM is therapeutically effective at a nonhypercalcemic dose.

$\mathrm{CD}^{+}$T-helper cells could be broadly divided into different effector cells such as Th1, Th2, and Th17 cells based upon their cytokines elaborated by these cells upon antigenic/mitogenic stimulation. The recent evidence indicates that Th17 cells are the key T cells involved in the pathogenesis of autoimmune diseases, whereas Th2 cells are involved in the pathology of allergic indications and produce IL-4, IL-5, IL-10, and IL-13 cytokines [24]. 1,25- $(\mathrm{OH})_{2} \mathrm{D}_{3}$ is regarded as an immunoregulatory hormone that in addition to its classical role on mineral homeostasis and maintenance of skeletal architecture also exhibits beneficial effects on Th17mediated autoimmune diseases. 1,25- $(\mathrm{OH})_{2} \mathrm{D}_{3}$ has shown efficacy in several autoimmune disease models, namely, systemic lupus erythematosus in lpr/lpr mice [28], type I diabetes in nonobese diabetic mice $[29,30]$, collage-induced arthritis [25], EAE [6], experimental autoimmune uveitis [31], and inflammatory bowel disease [26, 32]. Although $1,25-(\mathrm{OH})_{2} \mathrm{D}_{3}$ has demonstrated efficacy in preventing the incidence and progression of disease in the EAE model, the therapeutic activity was associated with accompanying hypercalcemia (Figure 8).

The VDRM, compound A, displayed many of the biological actions of $1,25-(\mathrm{OH})_{2} \mathrm{D}_{3}$. It induced RXR-VDR heterodimerization (Figure 1(a)), augmented VDR-LBDdependent gene expression in HeLa cells (Figure 2(a)), upregulated the expression of a VDRE-dependent gene, osteocalcin in osteoblasts (Figure 2(b)), inhibited IFN- $\gamma$, while augmenting IL-4, IL-5, and IL-10 cytokine elaboration in human PBMCs (Figure 5), and inhibited the expression of proinflammatory cytokines (IL-2, IFN- $\gamma$, and TNF $\alpha$ ) and induced the expression of anti-inflammatory cytokines IL-4 and IL-10 (Figure 6). It also induced the expression of GATA-3 (required for Th2 cell differentiation) in activated human PBMCs (Figure 6). More importantly, both 1,25$(\mathrm{OH})_{2} \mathrm{D}_{3}$ and compound A significantly inhibited Th17 cell differentiation (Figure 10), which is consistent with the recent observation made by Chang et al. (34). However, it was significantly less potent than its secosteroidal counterpart in inducing the expression of vitamin Dresponsive genes (TRPV6, Cyp24, and calbindin-9k) in differentiated Caco-2 as well as rat duodenal cells (Figure 3). These results indicate an attenuation of the VDR signaling pathway to compound A in intestinal cells. At the same time, the vitamin $\mathrm{D}$ signaling pathway still responds to 1,25- $(\mathrm{OH})_{2} \mathrm{D}_{3}$-complexed VDR for vitamin D-dependent gene expression in Caco-2 cells (Figure 3 ).

Studies with the VDR knockout animals have indicated duodenal TRPV6 to be a major mediator of 1,25$(\mathrm{OH})_{2} \mathrm{D}_{3}$-mediated calcium absorption from intestine and hypercalcemia [15]. Therefore, the weak agonist activity of compound A in human intestinal cells predicted that it might be less calcemic than $1,25-(\mathrm{OH})_{2} \mathrm{D}_{3}$ in vivo. In order to test this hypothesis, compound A was administered orally to mice in a 6-day murine model of hypercalcemia. The nonsecosteroidal VDRM was found to be at least 300 times less potent than $1,25-(\mathrm{OH})_{2} \mathrm{D}_{3}$ in inducing hypercalcemia by the oral route (Figure 7 ). The reduced calcemic liability of compound A prompted us to test it in a murine EAE model of MS. 1,25-(OH $)_{2} \mathrm{D}_{3}$ and its secosteroidal analogs have been shown to ameliorate EAE $[6,27]$. Here, we demonstrate that treatment of MOG-immunized animals with the nonsecosteroidal VDRM, compound A, delayed the onset of EAE and resulted in a less severe course of disease during the entire treatment period (Figure $8(\mathrm{a})$ ). 1,25- $(\mathrm{OH})_{2} \mathrm{D}_{3}$ on the other hand showed efficacy initially (till day 17 of the treatment) and delayed the onset of the disease. Interestingly, compound A did not raise the serum calcium levels above the normal range whereas $1,25-(\mathrm{OH})_{2} \mathrm{D}_{3}$ treatment of MOG immunized animals resulted in hypercalcemia (Figure $8(\mathrm{c})$ ). 
A plethora of epidemiological and pharmacological data demonstrating the connection between vitamin D and MS, coupled with our observation that a nonsecosteroidal VDRM ameliorates EAE, strongly supports the use of noncalcemic VDRMs as attractive candidates for the prevention and treatment of MS. Since VDR ligands have different mechanism of action from currently approved MS treatment, they may be more efficacious and useful in a combination therapeutic regimen.

\section{Acknowledgments}

The authors thank Ying K. Yee, Thomas P. Burris, Berket Khalifa, Jianfen Lu, and Xiao-Peng Yu, for their scientific contribution and skilled technical support.

\section{References}

[1] R. H. Swanborg, "Animal models of human disease. Experimental autoimmune encephalomyelitis in rodents as a model for human demyelinating disease," Clinical Immunology and Immunopathology, vol. 77, no. 1, pp. 4-13, 1995.

[2] G. G. Schwartz, "Multiple sclerosis and prostate cancer: what do their similar geographies suggest?" Neuroepidemiology, vol. 11, no. 4-6, pp. 244-254, 1992.

[3] A. E. Handel, G. Giovannoni, G. C. Ebers, and S. V. Ramagopalan, "Environmental factors and their timing in adult-onset multiple sclerosis," Nature Reviews Neurology, vol. 6, no. 3, pp. 156-166, 2010.

[4] K. L. Munger, S. M. Zhang, E. O’Reilly et al., "Vitamin D intake and incidence of multiple sclerosis," Neurology, vol. 62, no. 1, pp. 60-65, 2004.

[5] M. Soilu-Hänninen, L. Airas, I. Mononen, A. Heikkilä, M. Viljanen, and A. Hänninen, "25-Hydroxyvitamin D levels in serum at the onset of multiple sclerosis," Multiple Sclerosis, vol. 11, no. 3, pp. 266-271, 2005.

[6] M. T. Cantorna, C. E. Hayes, and H. F. Deluca, "1,25dihydroxyvitamin D reversibly blocks the progression of relapsing encephalomyelitis, a model of multiple sclerosis," Proceedings of the National Academy of Sciences of the United States of America, vol. 93, no. 15, pp. 7861-7864, 1996.

[7] D. J. Mangelsdorf, C. Thummel, M. Beato et al., "The nuclear receptor super-family: the second decade," Cell, vol. 83 , no. 6 , pp. 835-839, 1995.

[8] S. Nagpal, S. Na, and R. Rathnachalam, "Noncalcemic actions of vitamin D receptor ligands," Endocrine Reviews, vol. 26, no. 5, pp. 662-687, 2005.

[9] D. J. Bettoun, T. P. Burris, K. A. Houck et al., "Retinoid $\mathrm{X}$ receptor is a nonsilent major contributor to vitamin $\mathrm{D}$ receptor-mediated transcriptional activation," Molecular Endocrinology, vol. 17, no. 11, pp. 2320-2328, 2003.

[10] B. D. Lemon and L. P. Freedman, "Selective effects of ligands on vitamin D receptor- and retinoid X receptor-mediated gene activation in vivo," Molecular and Cellular Biology, vol. 16, no. 3, pp. 1006-1016, 1996.

[11] C. Rachez and L. P. Freedman, "Mechanisms of gene regulation by vitamin D receptor: a network of coactivator interactions," Gene, vol. 246, no. 1-2, pp. 9-21, 2000.

[12] M. Niino, "Vitamin D and its immunoregulatory role in multiple sclerosis," Drugs of Today, vol. 46, no. 4, pp. 279-290, 2010.
[13] Y. Ma, B. Khalifa, Y. K. Yee et al., "Identification and characterization of noncalcemic, tissue-selective, nonsecosteroidal vitamin D receptor modulators," Journal of Clinical Investigation, vol. 116, no. 4, pp. 892-904, 2006.

[14] R. Bouillon, W. H. Okamura, and A. W. Norman, "Structurefunction relationships in the vitamin D endocrine system," Endocrine Reviews, vol. 16, no. 2, pp. 200-256, 1995.

[15] S. J. Van Cromphaut, M. Dewerchin, J. G. J. Hoenderop et al., "Duodenal calcium absorption in vitamin D receptorknockout mice: functional and molecular aspects," Proceedings of the National Academy of Sciences of the United States of America, vol. 98, no. 23, pp. 13324-13329, 2001.

[16] F. Bronner, "Mechanisms of intestinal calcium absorption," Journal of Cellular Biochemistry, vol. 88, no. 2, pp. 387-393, 2003.

[17] L. Xiaodong and V. Huebner, "Non-steroidal ligands for steroid hormone receptors," Current Opinion in Drug Discovery and Development, vol. 3, no. 4, pp. 383-398, 2000.

[18] C. L. Smith and B. W. O'Malley, "Coregulator function: a key to understanding tissue specificity of selective receptor modulators," Endocrine Reviews, vol. 25, no. 1, pp. 45-71, 2004.

[19] G. Boguslawski, L. V. Hale, X. P. Yu et al., "Activation of osteocalcin transcription involves interaction of protein kinase A- and protein kinase C-dependent pathways," Journal of Biological Chemistry, vol. 275, no. 2, pp. 999-1006, 2000.

[20] R. J. Wood, L. Tchack, and S. Taparia, “1,25-Dihydroxyvitamin D3 increases the expression of the CaT1 epithelial calcium channel in the Caco-2 human intestinal cell line," $B M C$ Physiology, vol. 1, no. 1, article 11, p. 11, 2001.

[21] A. R. Giuliano and R. J. Wood, "Vitamin D-regulated calcium transport in Caco-2 cells: unique in vitro model," American Journal of Physiology, vol. 260, no. 2, pp. G207-G212, 1991.

[22] D. J. Mekala, R. S. Alli, and T. L. Geiger, "IL-10-dependent suppression of experimental allergic encephalomyelitis by Th2differentiated, anti-TCR redirected T lymphocytes," Journal of Immunology, vol. 174, no. 6, pp. 3789-3797, 2005.

[23] D. A. Fernandes de Abreu, D. Eyles, and F. Féron, "Vitamin D, a neuro-immunomodulator: implications for neurodegenerative and autoimmune diseases," Psychoneuroendocrinology, vol. 34, no. 1, pp. S265-S277, 2009.

[24] C. Mathieu and L. Adorini, "The coming of age of 1,25dihydroxyvitamin D analogs as immunomodulatory agents," Trends in Molecular Medicine, vol. 8, no. 4, pp. 174-179, 2002.

[25] M. T. Cantorna, C. E. Hayes, and H. F. DeLuca, "1,25Dihydroxycholecalciferol inhibits the progression of arthritis in murine models of human arthritis," Journal of Nutrition, vol. 128, no. 1, pp. 68-72, 1998.

[26] M. T. Cantorna, C. Munsick, C. Bemiss, and B. D. Mahon, "1,25-Dihydroxycholecalciferol prevents and ameliorates symptoms of experimental murine inflammatory bowel disease," Journal of Nutrition, vol. 130, no. 11, pp. 2648-2652, 2000.

[27] F. Mattner, S. Smiroldo, F. Galbiati et al., "Inhibition of Th1 development and treatment of chronic-relapsing experimental allergic encephalomyelitis by a non-hypercalcemic analogue of 1,25-dihydroxyvitamin D," European Journal of Immunology, vol. 30, no. 2, pp. 498-508, 2000.

[28] T. Koizumi, Y. Nakao, and T. Matsui, "Effects of corticosteroid and 1,24R-dihydroxy-vitamin D3 administration on lymphoproliferation and autoimmune disease in MRL/MPlpr/lpr mice," International Archives of Allergy and Applied Immunology, vol. 77, no. 4, pp. 396-404, 1985. 
[29] C. Mathieu, M. Waer, J. Laureys, O. Rutgeerts, and R. Bouillon, "Prevention of autoimmune diabetes in NOD mice by 1,25 dihydroxyvitamin D," Diabetologia, vol. 37, no. 6, pp. 552-558, 1994.

[30] C. Mathieu, M. Waer, K. Casteels, J. Laureys, and R. Bouillon, "Prevention of type I diabetes in NOD mice by nonhypercalcemic doses of a new structural analog of 1,25dihydroxyvitamin D, KH1060," Endocrinology, vol. 136, no. 3, pp. 866-872, 1995.

[31] J. Tang, R. U. Zhou, D. Luger et al., "Calcitriol suppresses antiretinal autoimmunity through inhibitory effects on the Th17 effector response," Journal of Immunology, vol. 182, no. 8, pp. 4624-4632, 2009.

[32] G. Laverny, G. Penna, S. Vetrano et al., "Efficacy of a potent and safe vitamin D receptor agonist for the treatment of inflammatory bowel disease," Immunology Letters, vol. 131, pp. 49-58, 2010. 


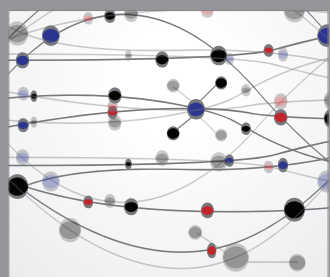

The Scientific World Journal
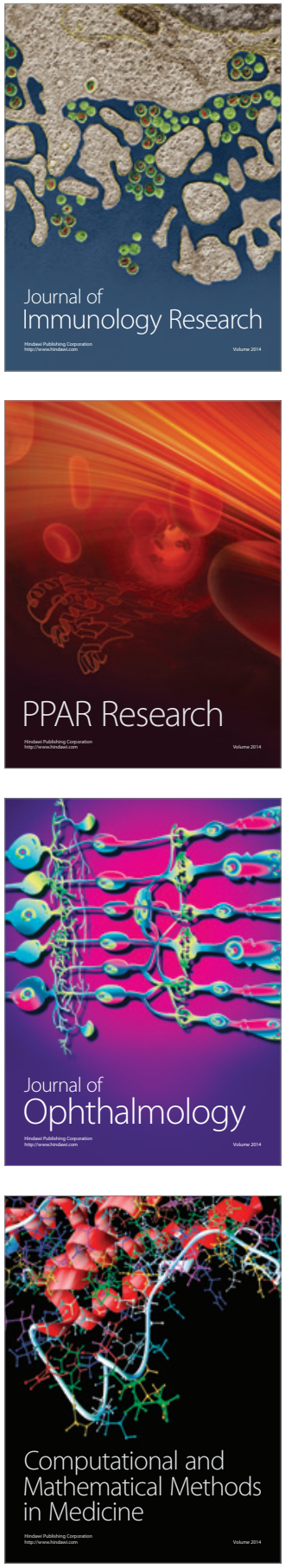

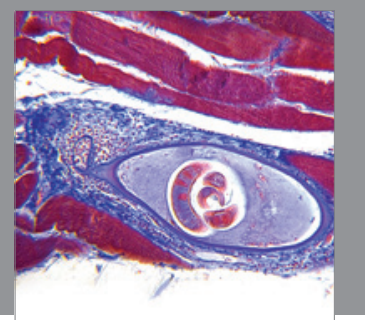

Gastroenterology

Research and Practice
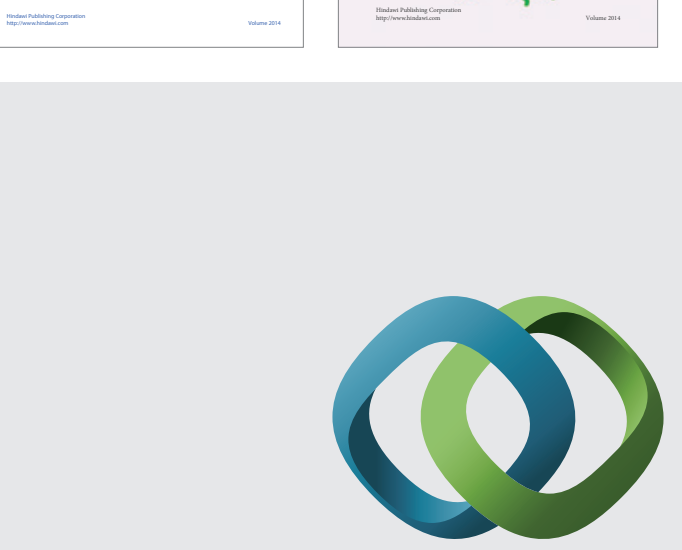

\section{Hindawi}

Submit your manuscripts at

http://www.hindawi.com
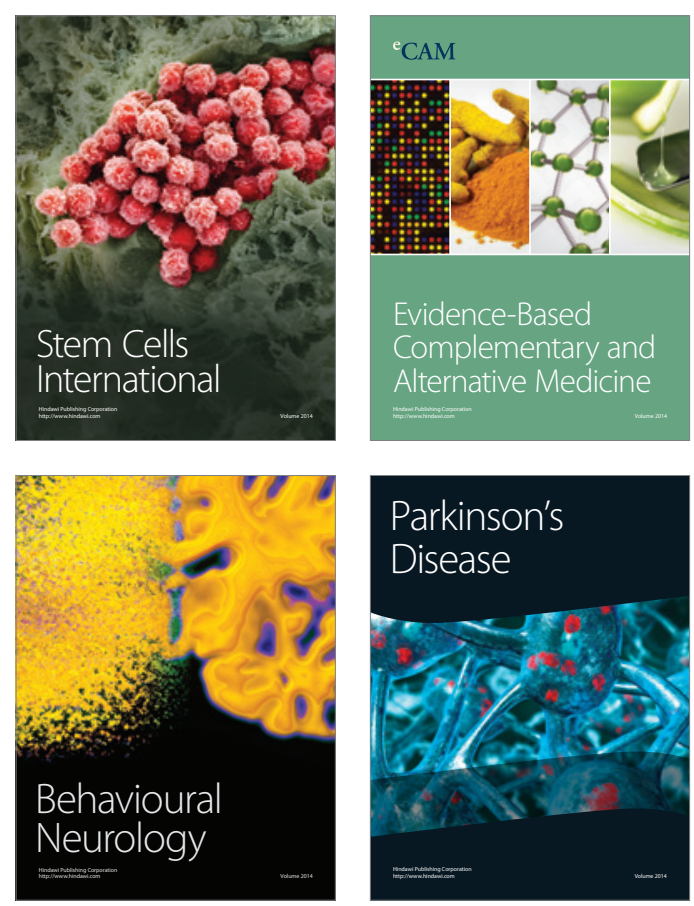

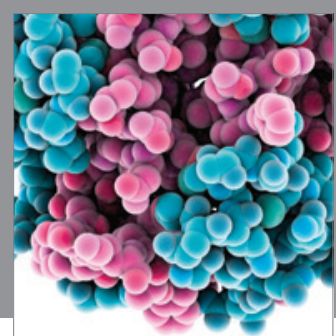

Journal of
Diabetes Research

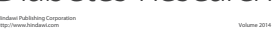

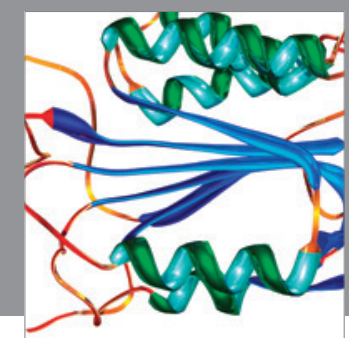

Disease Markers
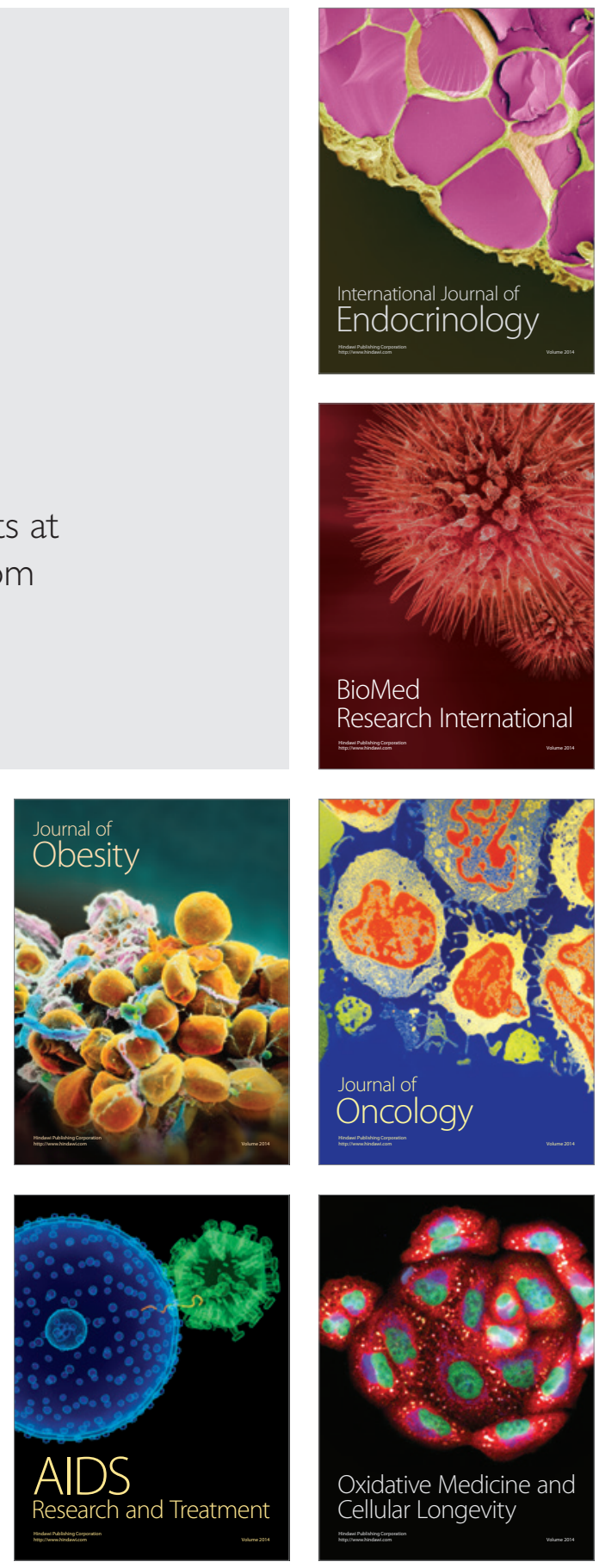